\title{
Nutritional Quality and Health Benefits of Vegetables: A Review
}

João Silva Dias

Technical University of Lisbon, Instituto Superior de Agronomia, Tapada da Ajuda, Portugal.

Email: mirjsd@gmail.com

Received July $9^{\text {th }}, 2012$; revised August $9^{\text {th }}, 2012$; accepted August $16^{\text {th }}, 2012$

\begin{abstract}
Vegetables are considered essential for well-balanced diets since they supply vitamins, minerals, dietary fiber, and phytochemicals. Each vegetable group contains a unique combination and amount of these phytonutriceuticals, which distinguishes them from other groups and vegetables whithin their own group. In the daily diet vegetables have been strongly associated with improvement of gastrointestinal health, good vision, and reduced risk of heart disease, stroke, chronic diseases such as diabetes, and some forms of cancer. Some phytochemicals of vegetables are strong antioxidants and are thought to reduce the risk of chronic disease by protecting against free radical damage, by modifying metabolic activation and detoxification of carcinogens, or even by influencing processes that alter the course of tumor cells. All the vegetables may offer protection to humans against chronic diseases. Nutrition is both a quantity and a quality issue, and vegetables in all their many forms ensure an adequate intake of most vitamins and nutrients, dietary fibers, and phytochemicals which can bring a much-needed measure of balance back to diets contributing to solve many of these nutrition problems. The promotion of healthy vegetable products has coincided with a surging consumer interested in the healthy functionality of food. Because each vegetable contains a unique combination of phytonutriceuticals, a great diversity of vegetables should be eaten to ensure that individual's diet includes a combination of phytonutriceuticals and to get all the health benefits. This article makes a review and discusses the nutritional quality and health benefits of the major groups of vegetables. More interdisciplinary work is required that involves nutritional and food scientists as well as others from biomedical fields to ascertain the thrue function of specific phytonutriceuticals.
\end{abstract}

Keywords: Antioxidants; Dietary Fiber; Horticulture; Phytochemicals; Phytonutriceuticals

\section{Introduction}

Vegetables make up a major portion of the diet of humans in many parts of the world and play a significant role in human nutrition, especially as sources of phytonutriceuticals: vitamins (C, A, B1, B6, B9, E), minerals, dietary fiber and phytochemicals [1-4]. Some phytochemicals of vegetables are strong antioxidants and are thought to reduce the risk of chronic disease by protecting against free-radical damage, by modifying metabolic activation and detoxification of carcinogens, or even influencing processes that alter the course of tumor cells $[2,3,5,6]$. Vegetables in the daily diet have been strongly associated with overall good health, improvement of gastrointestinal health and vision, reduced risk for some forms of cancer, heart disease, stroke, diabetes, anaemia, gastric ulcer, rheumatoid arthritis, and other chronic diseases [7-11]. A high vegetable diet has been associated with lower risk of cardiovascular disease in humans [12]. Low vegetable intake, in unbalanced diets, has been estimated to cause about $31 \%$ of ischaemic heart disease and $11 \%$ of stroke worldwide. According to the 2007 World Health Report unbalanced diets with low vegetable intake and low consumption of complex carbohydrates and dietary fiber are estimated to cause some 2.7 million deaths each year, and were among the top 10 risk factors contributing to mortality [13]. The exact mechanisms by which vegetable consumption reduces human diseases have not yet been fully understood, however the general consensus among physicians and nutritionists is that phytonutriceuticals in vegetables are responsible for mitigating some of these diseases.

A world vegetable survey showed that 402 vegetable crops are cultivated worldwide, representing 69 families and 230 genera $[14,15]$. Leafy vegetables - of which the leaves or young leafy shoots are consumed-were the most often utilized ( $53 \%$ of the total), followed by vegetable fruits $(15 \%)$, and vegetables with below ground edible organs comprised $17 \%$. Many vegetable crops have more than one part used. Most of the vegetables are marketed fresh with only a small proportion processed 
because most vegetables are perishable. Consumption shortly after harvest guarantees optimal vegetable quality. Nutrition is both a quantity and a quality issue, and vegetables in all their many forms ensure an adequate intake of most vitamins and nutrients, dietary fibers, and phytochemicals which can bring a much-needed measure of balance back to diets contributing to solve many of these nutrition problems.

Only $67(17 \%)$ of commercial vegetables have attracted investments for crop breeding by multinational seed corporations, due to their large area of production and substantial consumption, $52(13 \%)$ vegetables were considered minor, and other $87(22 \%)$ species were considered rare [13]. In 2010 the global vegetable seed market was estimated at US $\$ 4.1$ billion, of which $36 \%$ were for solanaceous, $21 \%$ for cucurbits, $13 \%$ for roots and bulbs, $12 \%$ for large seed, $11 \%$ for brassicas, and $7 \%$ for leafy and others vegetables [16]. Global commercial vegetable seed sales had an annual growth rate of $5.8 \%$ in the last decade [13]. With the increase in world population and consumption the global market of vegetable seeds is expected to expand in future years.

The promotion of healthy vegetable products has coincided with a surging consumer interested in the healthy functionality of food. There is an increasing awareness among the general public of the advantages of diets rich in vegetables to ensure an adequate intake of most vitamins and micronutrients, dietary fibers, and phytochemicals that promote health. Consumers interest in whole foods with enhanced nutitional qualities is at an all-time high, and more consumers are choosing foods on the basis of their healthy benefits. This article makes a review and discusses the nutritional quality and health benefits of the major groups of vegetables.

\section{Nutritional Quality and Health Benefits of Vegetables}

\subsection{Introduction}

There are a general belief among nutritionists and health profissionals that the health benefit of vegetables should not be linked to only one compound or one type of vegetable, but rather a balanced diet that includes more than one type of vegetable is likely to provide better protection. All the vegetables may offer protection to humans against chronic diseases. Whith the exception of glucosinolates and thiosulfides, which are unique to the crucifers and alliums, the phytonutriceuticals content of a number of other vegetales consist primarily of vitamin $\mathrm{C}$, fiber, selenium, folate and polyphenolics (carotenoids and flavonoids). The main difference is that each vegetable group contains a unique combination and amount of these phytonutriceuticals, which distinguishes them from other groups and vegetables whithin their own group. For example the Apiaceae family (e.g. celery, parsley, carrot) is rich in flavonoids, carotenoids, vitamin $\mathrm{C}$, and vitamin E. Celery and parsley for example are among the best vegetables sources for the flavonoid apigenin and vitamin E [17], and carrots have an unique combination of three flavonoids: kaempferol, quercetin, and luteolin [1820]. In carrot, overall carotenoid levels, have increased dramaticaly in the past four decades through traditional breeding to reach levels of 1000 ppm carotenoids, on a fresh weight basis [21]. The Asteraceae or Compositae family (e.g. lettuce, chicory) is rich in conjugated quercetin, flavonoids, and tocopherols. Crozier et al. [22] observed sizeable variations in flavonol content were also observed with lettuce cultivars by these authors [22]. The commonly consumed small "round" lettuce contained only $11 \mu \mathrm{g} / \mathrm{g}$ fresh weight of quercetin, and the levels in "iceberg" lettuce were even lower. In contrast, the outer leaves of "Lollo Rosso", a red cultivar of lettuce, contained $911 \mu \mathrm{g} / \mathrm{g}$. The red color of this lettuce is due to high levels of anthocyanins, which like quercetin, are products of the phenylpropanoid pathway. As one endproduct of the pathway has been elevated, it may well be that other related compounds, including the flavonols, are also found in higher concentrations. Roman lettuce is richer in lutein than head lettuces; and leafy and roman lettuces are richer in quercetin [23]. The Cucurbitaceae family (e.g. pumpkin, squash, melon, cucumber) is rich in vitamin C, carotenoids, and tocopherols [24]. Burger et al. [25] in a survey of 350 melon accessions from different horticultural groups of Cucurbita melo observed a 50 -fold variation in ascorbic acid content, ranging from $0.7 \mathrm{mg}$ to $35.3 \mathrm{mg} / 100 \mathrm{~g}$ of fresh fruit weight. Ascorbic acid and $\beta$-carotene content ranged from 7.0 to 32.0 $\mathrm{mg} / 100 \mathrm{~g}$ and 4.7 to $62.2 \mu \mathrm{g} / 100 \mathrm{~g}$, respectively in sweet melons [26]. Bitter gourd (Momordica charantia) has anti-diabetic properties and can be used to ameliorate the effects of type-2 diabetes. Diet is the primary therapy for this type of diabetes and bitter gourd is particularly critical when pharmaceuticals are not available, as happens in a great part of the developing world [4]. The Chenopodiaceae family (e.g. spinach, Swiss chard, beet greens) is an excellent source of folate [27] and have been shown to inhibit DNA synthesis in proliferating human gastric adenocarcinoma cells [28]. The Chenopodiaceae vegetables are also among the most oxalate dense vegetables $[29,30]$. When oxalates become too concentrated in body fluids, they can crystallize and cause health problems such as kidney calcium oxalate stones. All the legumes (Fabaceae or Leguminosae family; e.g. bean, pea, soybean, chickpea, lentils), mature and imature seeds are good sources of dietary fiber and isoflavonoids [31]. Mallillin et al. [32] determined the total, soluble and insoluble fibre and fermentability characteristics of ten legumes mature seeds (mungbean, soyabean peanut, 
pole sitao, cowpea, chickpea, green pea, lima bean, kidney bean and pigeon pea) and concluded that the dietary fibre content ranged from 20.9 to $46.9 \mathrm{~g} / 100 \mathrm{~g}$ and that the best sources after in vitro fermentation using human faecal inoculum stimulating conditions in the human collon (as $\mathrm{mmol} / \mathrm{g} /$ fibre isolate of acetate, propinate, butyrate produced after fibre fermentation measured by HPLC) were pole sitao and mungbean (acetate), kidney bean and pigeon pea, (propinate), and peanut and cowpea (butyrate). High-flavonol legumes include sugar snap peas and mange-tout, which were found to contain 98 and 145 $\mu \mathrm{g}$ quercetin/g respectively. Some legumes are also rich in iron. Trinidad et al. [33] determined the mineral availability in vitro of iron, zinc and calcium in ten local legumes (cowpeas, mung beans, pole sitao, chickpeas, green peas, groundnuts, pigeon peas, kidney beans, lima beans and soyabeans). They found that the highest iron availability among legumes was for lima beans $(9.5$ (sem $0.1)$ ) and mung bean while for zinc and calcium, the highest availability was for kidney beans (49.3 (sem 4.5)) and pigeon peas (75.1 (sem 7.1)), respectively. Groundnuts have the lowest $\mathrm{Fe}$ (1.3 (sem 1.1)), Zn (7.9 (sem 1.3)) and $\mathrm{Ca}$ (14.6 (sem 2.8)) availability. They concluded that mineral availability of $\mathrm{Fe}, \mathrm{Zn}$, and $\mathrm{Ca}$ from legumes differs and may be attributed to their mineral content, mineral-mineral interaction and from their phytic and tannic acid content. For example mungbean (Vigna radiata) either eaten as whole pod grains or grown to produce bean sprouts, is an important source of iron for women and children throughout South Asia [13].

In this section we will highlight the health benefits of the most studied and consumed vegetables namely crucifer, allium and solanaceous vegetables.

\subsection{Crucifers}

Cruciferous vegetables (Brassicacea or Cruciferae family) which include, cabbage, brocolli, cauliflower, Brussels sprouts, kales, kailan, chinese cabbage, turnip, rutabaga, radish, horseradish, rocket, watercress, mustards, among other vegetables, provide the richest sources of glucosenolates in the human diet. Most consumers associate cruciferous vegetable consumption with health. They have reasons for that because based on one of the largest and most detailed reviews of diet and cancer, the World Cancer Research Fund in USA [34] concluded that a diet rich in crucifers is likely to protect humans against colon, rectum, and thyroid cancers, and when consumed with vegetables rich in other phytonutriceuticals, can protect against cancer in other organs. Crucifers rich in glucosenolates including broccoli, cabbage, Brussels sprouts, and kale have been shown to protect against lung, prostate cancer, breast cancer, and chemically induced cancers [35-39]. Epidemiological data show that a diet rich in crucifers can reduce the risk from several types of cancers and that the risk can be significantly reduced by an intake of at least $10 \mathrm{~g}$ per day [35,36,38-41]. Epidemiological studies have suggested that diets rich in broccoli, may reduce the risk of prostate cancer, and consumption of one or more portions of broccoli per week can reduce the incidence and the progression from localized to aggressive forms of prostrate cancer [38,39].

The overwhelming evidence concerning the anticarcinogenic effect of phytonutriceuticals in crucifers were from in vivo studies, mainly with broccoli, using animal models and human Volunteers [36,38-45]. In order to establish the relationship between whole broccoli and cancer prevention, Farnham et al. [46] examined the diversity of induction of the phase II detoxification enzyme quinone reductase, in murine hepatoma cells, by 71 inbred and 5 hybrid lines of broccoli. They found that the rate of induction of quinone reductase in hepa $1 \mathrm{c} 1 \mathrm{c} 7$ by the broccoli inbred lines ranged from 0 to 15,000 units and that the rate of induction was highly correlated (average $r=0.85, P=0.0001)$ to the concentration of glucoraphanin in each broccoli inbred. These results suggest that there are significant differences in the health benefits among crucifers, which is important not only from a health point of view, but also as a marketing tool to promote a certain cultivar. Comparative studies of glucosenolate profiles indicate significant quantitative and quailtative differences among accessions within each crucifer, between plant parts, developmental stage, agronomic management, and climatic conditions [47-59]. Kushad et al. [53] observed in 65 cultivars of brocolli, that glucoraphanin was the major glucosinolate and that there was more than 27-fold difference between the highest concentration in cultivar "Brigadier" and the lowest concentration in cultivar "EV6-1". Hansen et al. [60] also observed in their study with 21 cultivars of red cabbage and 6 white cabbages, that there was a considerable variation in the concentration of the individual glucosenolates between the cultivars examined. Red cabbage cultivars were found to contain significantly higher concentrations of glucoraphanin compared to white cabbage cultivars. There were also significant differences within the red cabbage cultivars. Of the red cultivars examined "Rodima" had the highest concentration with $7.4 \mathrm{mg} / \mathrm{g}$ DW glucoraphanin whereas "Primero" has the lowest concentration containing only $0.6 \mathrm{mg} / \mathrm{g} \mathrm{DW}$. The white cabbage cultivars contained significantly higher levels of glucoiberin compared to red cultivars. The white cabbage cultivar "Bartolo" contained the highest level of $7.4 \mathrm{mg} / \mathrm{g}$ dry weight, whereas the cultivar "Candela" had the lowest level of $1.7 \mathrm{mg} / \mathrm{g}$ dry weight. The red cultivars ranged from approximately $3 \mathrm{mg} / \mathrm{g}$ dry weight to $0.3 \mathrm{mg} / \mathrm{g}$ dry weight. The red cabbages were also found to contain significantly higher concentration of gluconasturtiin com- 
pared to white cabbage cultivars. The cultivar "Amager Garo" had the highest concentration whereas "Primero" had the lowest, 1 and $0.1 \mathrm{mg} / \mathrm{g}$ dry weight, respectively. Similar differences were also observed in turnip and rutabagas [49]. Fahey et al. [61] evaluated glucosinolate content of broccoli sprouts and found that they contain nearly 20 - to 50 -fold higher glucosinolates than tissue from mature plants. In broccoli heads, the most significant glucosinolates are glucoraphanin, glucobrassicin, progoitrin, and gluconasturtiin $[51,53,55,56,58,62]$. In cabbage, Brussel sprouts, cauliflower, kale, tronchuda and collard the predominant glucosinolates are sinigrin, progoitrin, and glucobrassicin [48,51,53,59,60,63]. In turnip and rutabagas, the predominant glucosenolates are glucoerucin, glucoraphanin, and glucobrassicin [49,52]. In radish, the predominant glucosinolates are glucoerucin, glucoraphanin, and glucobrassicin [50,54]. Each of these crucifers also contain smaller amounts of other glucosinolates. The bulk of the differences in the aliphatic glucosinolates is genetically regulated [64-66]. Differences in the indol glucosinolates, in contrast to aliphatic glucosinolates, have been attributed to environmental factors. Even though the glucosinolate content is influenced by environmental conditions the effect of genotype is found to be greater than that of environ- mental factors [46].

Crucifer vegetables are also rich in vitamins, with kale rated as the second highest among 22 vegetables tested [67]. Brussels sprouts and broccoli were also ranked high in their vitamin content containing significant amounts of vitamins $\mathrm{C}$ and $\mathrm{E}$, and $\beta$-carotene [68]. Evaluation of $\alpha$ and $\beta$-, $\alpha$-, and $\gamma$-tocopherols, and vitamin $\mathrm{C}$ in broccoli, Brussels sprouts, cabbage, cauliflower, tronchuda, and kale, showed significant variations between and within these crucifers $[53,68]$. Vitamin $\mathrm{C}$ is the most abundant vitamin in all five crucifers tested [68]. Kale had the highest amount of these vitamins, followed by broccoli, Brussels sprouts, cabbage and cauliflower. Analysis indicated that $79 \%$ of $\beta$-carotene, $82 \%$ of $\alpha$-tocopherol, and $55 \%$ of vitamin $\mathrm{C}$ variability in broccoli were associated with genetic factors [68]. Crucifers are also excellent source of folate. Brussels sprouts and broccoli were ranked among the highest vegetable sources for folate, contributing about 110 to 135 and 70 to $90 \mu \mathrm{g} / 100 \mathrm{~g}$, respectively $[27,69]$.

Crucifers also contain significant amounts of dietary fiber. Dietary fiber content of cauliflower was estimated to be about $5 \%$ of the total fresh weight or about $50 \%$ of the total dry weight, consisting of about $40 \%$ nonstarch polysaccharides [70]. Cellulose and lignin concentrations in Brussels sprouts were estimated to be $36 \%$ and $14.5 \%$, while in cauliflower they were estimated to be about $16 \%$ and $13 \%$ of the total dry matter, respectively [71].

There are plenty of crucifers (e.g. kales, tronchuda cabbages, pack-choy, kailan, rutabaga, turnip, Brussels sprouts, etc.) that are good sources of calcium. Galega kale contains a high content of protein, fiber, calcium, and sulfur when compared to broccoli, the reference within Brassica vegetables. Crucifers are capable of accumulating substantial amounts of selenium when grown on high-selenium soil. Banuelos and Meek [72] reported that broccoli grown on selenium enriched soil accumulated sevenfold more selenium than cabbage, collards and Swiss chard. Broccoli plants grown outdoors on a sphagnum, peatmoss, and vermiculite medium and fertilized with sodium-selenate and selenite accumulated 278 $\mathrm{mg} / \mathrm{g}$ dry weight selenium, in the edible florets, compared to the nonfertilized control, which accumulated only $0.13 \mathrm{mg} / \mathrm{g}$ dry weight [73]. In broccoli, selenium is stored as selenocysteine [74], which is readily absorved by human tissue. Selenium-enriched broccoli has been found to reduce colon cancer and mammary tumors in animal models [73,75]. Cabbage sprouts and fully developed heads also accumulated selenium and the accumulation was higher in the sprouts than in the mature heads [76].

Other antioxidants in crucifers include flavonoids. Miean and Mohamed [77] examined the flavonoid content of 62 vegetables and found that broccoli, cauliflower, cabbage, chinese cabbage, and kailan contained between 148 and $219 \mathrm{mg} / \mathrm{kg}$ of flavonoids. Broccoli contained myricetin, quercetin, and luteolin; cauliflower contained myricetin and quercetin; kailan contained quercetin and apigenin; while cabbage contained only myricetin. In a similar study, Hertog et al. [78] evaluated the methanolextracted flavonoids from 28 vegetables and found that quercetin levels, in the edible part of most vegetables, were below $10 \mathrm{mg} / \mathrm{kg}$, except in kale $(110 \mathrm{mg} / \mathrm{kg})$, broccoli $(30 \mathrm{mg} / \mathrm{kg}$ ), and onion $(486 \mathrm{mg} / \mathrm{kg})$. Kale, broccoli and turnip contained 211,72 , and $48 \mathrm{mg} / \mathrm{kg}$ of kaempferol, respectively. Kaempferol had also been detected in cabbage leaves [79], but Miean and Moamed [77] did not detect kaempferol in any of the tested crucifer vegetables.

\subsection{Alliums}

Alliums vegetables (Alliaceae family) include, garlic, onion, leek, chive, Welsh onion, among other vegetables. They are rich in a wide variety of thiosulfides, which have been linked to reducing various chronic diseases. Similar to glucosinolates in crucifers, the types and amounts of thiosulfides in alliums vary significantly. Typically, they contain $1 \%$ to $5 \%$ nonprotein sulfur compounds, on a dry weight basis [80]. Kubec et al. [80] reported significantly variability in the total thiosulfide ( $0.02 \%$ to $1.3 \%$ fresh weight) content and in the relative proportion of these compounds between and within alliums, even when grown under identical conditions. They 
found that the total thiosulfide contents in green onion leaves, chive, and onion bulb were $0.2,0.72$, and 1.02 $\mathrm{g} / \mathrm{kg}$ fresh weight, respectively. The type of thiosulphides in these vegetables were also variable. For example onion bulbs contained $34 \%$ methiin, $5 \%$ ethiin, $6 \%$ propiin, $5 \%$ alliin, and $49 \%$ isoalliin [80], while garlic cloves contained about $92 \%$ alliin, $8 \%$ methiin, and trace amounts of ethiin, propiin, and isoalliin [81].

The second most important group of phytonutriceuticals in alliums are flavonoids. Two types of flavonoids are found in onion bulbs: anthocyanins in red onions and flavonols like quercetin and kaempferol in most yellow fresh cultivars. Miean and Mohamed [77] reported that onion leaves had the highest total flavonoid content among 62 different vegetables they tested and that total flavonoid content of onion leaves and garlic were about 2.7 and $1.0 \mathrm{~g} / \mathrm{kg}$ dry weight, respectively [77]. In onion leaves, about $55 \%$ of the total flavonoids is quercetin, $31 \%$ kaempferol, and $14 \%$ luteolin. In onion bulb, more than $95 \%$ of the flavonoids is quercetin and only a trace amount of kaempferol [78]. White onion cultivars were reported to have significantly less quercetin than the red ones and most of the quercetin is present in the outer scales [82]. Red onions contained approximately 1350 $\mu \mathrm{g} / \mathrm{g}$ fresh weight of total flavonols and white onions contained only $10 \mu \mathrm{g} / \mathrm{g}$. Quercetin in onion appeared mainly in the free-form as the aglycone [82]. In garlic cloves, $72 \%$ of the total flavonoids is myricetin, $23 \%$ apigenin, and 5\% quercetin [77]. In chive, garlic chive, and leek the predominant flavonoid is kaempferol [83].

Onion and garlic are an excellent source of calcium, potassium and manganese providing up to $10 \%$ of the human daily requirements of these elements. Onion and garlic can also accumulate selenium if grown in selenium-rich soils in the form of selenocystein and selenoproteins. Based on this information Ip and Lisk [84] showed that garlic plants fertilized with high selenium and low sulfur fertilizer accumulated between 110 and 150 ppm dry weight selenium, while onion plants accumulated up to $28 \mathrm{ppm}$. Ip and Lisk [84] proposed that the selenium enriched garlic and onion provide an ideal system to deliver selenium efficiently and safely into the human body for cancer prevention since inhibition of cancer by selenium in animal models requires between 1 to $3 \mathrm{ppm}$ [85]. Most of the onions and garlics contain very low concentrations of selenium. Ip and Lisk [84] reported that "Valencia" topset garlic cloves contained $0.06 \mathrm{ppm}$ selenium, while "Stuttgart" onion bulbs contained $0.02 \mathrm{ppm}$. Interestingly, onions also contain chromium and are considered a good source of this element. Chromium has been recently linked to diabetes prevention and appears to act as such by potentiating insulin receptor kinases [86] and to be a part of the glucose tolerance factor, involved in cellular responses to insulin.
Clinical studies on diabetic patients have shown that chromium can decrease fasting glucose levels, improve glucose tolerance, lower insuline levels and decrease total cholesterol and triglycerid levels. Two hundred grams of onions contain up to $20 \%$ of the daily requirements in chromium.

Onions are a rich source of dietary fibers and especially of inulin, a polyfructosan. The health benefits of inulin-type fructans to human health have now been studied for more than one decade [87]. It has prebiotic properties as it is preferably fermented by beneficial bowel bacteria like Lactobacilli and Bifidobacteria, thereby altering the bacterial mycoflora of the intestine in such a way that pathogenic, or harmful bacteria become less abundant [88]. Neokestose, another fructan found in onion, has recently been shown to be an excellent promoter of the growth of beneficial bacteria [89]. Frutans also promote the absorption of calcium and could thus be useful in the prevention of osteoporosis [90]. High fructan diets have also been shown to lower concentration of colesterol, tryacylglycerol, phospholipids, glucose and insulin in the blood of middle-aged men and women [91]. Owing to the presence of prebiotic polysaccharides (inulin), which are poorly degraded by the gut enzymes, and the presence of flavonoids, onions have been shown to possesss antidiabetic potential [92]. Sharma et al. [93] showed that onions had antihyperglycemic effects. Such effects were confirmed by Tjokroprawiro et al. [94] who conducted a crossover comparative study with twenty diabetic patients to assess the effect of a diet comprising onions and green beans on serum glucose levels. They showed that the consumption of $20 \mathrm{~g}$ fresh onion three times daily significantly reduced blood sugar levels.

The therapeutic value of onions, garlic and other $\mathrm{Al}$ lium vegetables is confirmed by multiple epidemiological and experimental studies. Consumption of Allium vegetables has been found to retard growth of several types of cancers. For instance, there appears to be a strong link between the consumption of onions and the reduced incidence of stomach and intestine cancers [95,96]. A number of epidemiological studies show inverse correlations between the consumption of alliums like onions and garlics, and the reduced incidence of cancers. A synthesis of case control studies carried in Italy and Switzerland reveals that consumption of one to seven portions of onions per week reduces the risks of colon, ovary, larynx, and mouth cancers [97]. Other epidemiological studies clearly show the correlation between moderate garlic intake and a low esophageal and stomach tract cancers incidence [97-99]. These studies have been performed on diferent geographical areas/continents and countries: China [100,101], Japan [102], Netherlands [103], Italy [104], Hawaii [105], Venezuela [106], Uruguay [107]. Overall, a protective effect was reported, despite the ob- 
vious genetic variance existing among the populations examined in the different studies. A regular consumption of garlic has been associated with the reduction in the incidence of preneoplastic lesions occurring in the gastric mucosa of individuals infected by Helicobacter pylori [100]. A reduced cancer risk has been widely documented also for colorectal and prostate cancers [97,99, $108,109]$. Other studies analyzing the preventive effect of garlic extracts on colorectal cancer have evidenced their suppressive potential on the development and progresssion of colorectal adenomas [110,111]. A population based study analyzing the impact of a diet rich in Allium vegetables on the incidence of prostate cancer showed that the anti-cancer effects were more pronounced in men presenting localized rather than advanced forms [109]. Mortality due to prostate cancer also appears to be reduced by a diet making a large place for onions [112]. A limited number of studies explored the impact of a regular intake of Allium vegetables on the incidence of cancers affecting breast, endometrium and lungs [113-115]. The risk of breast cancer was shown to decrease as consumption of alliums was increased in a French case-control study [113]. It was found that garlic and some of its constituents prevent tumor initiation by inhibiting the activation of pro-carcinogens and by stimulating their elimination [116-118]. Some studies say that onion extracts can inhibit the mutation process [119] and reduce the proliferation of cancer cells [120]. This effect is being attributed to quercetin in particular.

Prevention of cardiovascular diseases has been attributed to regular garlic consumption. Onions also contain a number of bioactive molecules that can presumably reduce the risks for cardiovascular diseases [121]. A preliminary study conducted in humans showed that the consumption of the equivalent of three onions in a soup was sufficient to significantly reduce the blood platelet aggregation [122].

\subsection{Solanaceous Vegetables}

The use of solanaceous vegetables in traditional medicine is ancient. There are significant differences in the phytonutreucical content between solanaceous vegetables, and therefore each vegetable will be examined separately.

\subsubsection{Tomato}

Tomato is the second most consumed and widely grown vegetable in the world after potato. Tomato is popular fresh and in many processed forms (e.g. ketchup, canned whole or in pieces, puree, sauce, soup, juice, or sundried). In addition to their culinary role in the diet, tomatoes represent a low energy dense food with unique constituents that may positively affect health. Compositionally, the tomato has a unique nutritional and phyto- chemical profile. The major phytochemicals in tomato are the carotenoids consisting of $60 \%$ to $64 \%$ lycopene, $10 \%$ to $12 \%$ phytoene, $7 \%$ to $9 \%$ neurosporene, and $10 \%$ to $15 \%$ carotenes [123]. Based on a fresh weight basis, tomato (on average) contains about $35 \mathrm{mg} / \mathrm{kg}$ of lycopene, with red cultivars containing in average $90 \mathrm{mg} / \mathrm{kg}$ of lycopene and yellow ones only $5 \mathrm{mg} / \mathrm{kg}$ [124]. Processed tomatoes (sauce, paste, juice, and ketchup) contain 2 - to 40 -fold higher lycopene than fresh tomatoes [123, $125,126]$.

Tomatoes and tomato-based foods are the world richest sources of lycopene. The average daily intake of lycopene in the human diet is about $25 \mathrm{mg} /$ day; nearly 85 percent is obtained from fresh and processed tomato products [126,127]. Tomato contains significant amounts of $\alpha-, \beta-, \gamma-, \delta$-carotene ranging in concentrations form 0.6 to $2.0 \mathrm{mg} / \mathrm{kg}[128,129]$, which ranks tomato as the fourth leading-contributor of provitamin A and vitamin A in the American diet [130,131].

In addition to lycopene, tomatoes are one of the top contributors of potassium in developed countries and in the American diet [132]. Based on a 1999-2000 USA National Health and Nutrition Examination Survey food intake data, tomatoes rank seventh after milk, potatoes, beef, coffee, poultry, and orange/grapefruit juice as a potassium source. Besides in USA potassium is a nutrient of concern, as most Americans consume amounts well below the Dietary Reference Intake (DRI). In 2004, the new adult DRI for potassium (4700 mg) was substantially higher than the amount previously reported in the 1989 Recommended Dietary Allowance (3500 mg) [133, 134]. The increased recommendation was based on evidence indicating that $4700 \mathrm{mg}$ potassium should help lower blood pressure, reduce the adverse effect of excess sodium intake on blood pressure, reduce the risk of kidney stones, and possibly reduce age-related bone loss. Tomatoes provide at least twice the potassium per 100 kcal compared with other common sources, except coffee, a nonsignificant calorie source of potassium. Consuming potassium from fruits and vegetables is ideal because it occurs with a biologically advantageous ratio of bicarbonate or citrate, important for bone health. Increasing potassium intake through increased tomato intake is a healthful, calorically sensible strategy for world developed countries.

Tomato fruits are also an excellent source of ascorbic acid, about $200 \mathrm{mg} / \mathrm{kg}$ and are the major source of vitamin $\mathrm{C}$ next to citrus [135]. Tomato contains small but significant amounts $(1-2 \mathrm{mg} / \mathrm{kg})$ of lutein, $\alpha-, \beta$-, and $\gamma-$ tocopherols, and conjugated flavonoids $[128,129,136]$. In a study of 20 tomato cultivars, total flavonoids content ranged from 1.3 to $22.2 \mathrm{mg} / \mathrm{kg}$ with about $98 \%$ present in the skin [137]. Flavonoids in fresh tomato are present only in the conjugated form as quercetin and kaempferol 
[138], but processed tomato products contain significant amounts of free flavonoids [137]. Flavonoids content is affected by cultivar and culture. For example, cherry tomatoes have a markedy d higher flavonoids content than standard or beef tomato cultivars and field-grown fruits have higher flavonoids content than greenhousegrown $[21,137]$. Tomato cultivars are available with double the normal vitamin $\mathrm{C}$ (Doublerich), forty times normal vitamin A (97L97), high levels of anthocyanin (resulting in purple tomatoes), and two to four times the normal amount of lycopene (numerous available cultivars with the high crimson gene).

Tomato lycopene is found in appreciable levels in human serum and tissues when tomatoes and tomato products are consumed frequently [139-141]. Several research investigations have shown an inverse relationship between plasma/serum lycopene concentrations and risk of some cancers [142-148]. Similar associations have been reported for markers of cardiovascular disease, osteoporosis, cognitive function, and body weight [149-156]. Moreover, relationships between dietary intakes of tomato products or tomato extract supplements have been observed in epidemiological studies and clinical trials examining markers of some cancers, cardiovascular disease, and ultraviolet light-induced skin erythema [157172].

The majority of research conducted in the area of tomato and lycopene intake and cancer risk has been observational. In a recent review of the literature, 178 original research articles were compiled reporting findings in humans on the relationship between lycopene, tomatoes and tomato-based products, and cancer risk [173]. Among these publications, nearly $90 \%$ were observational, highlighting the paucity of cause and effect investigations in this area. Reports on 13 cancer types were identified, of which breast, colorectal, gastric/upper gastrointestinal, and prostate cancers have the most original research published in humans, ranging from 17 to 60 publications. For breast, colorectal, and gastric cancers, the data support a neutral, although potentially protective, relationship between tomato/lycopene intake and cancer risk. Although the data are limited for gastric and lung cancers; the protective association is strongest with tomato intake verses dietary lycopene intake. Among the cancers investigated relative to lycopene and tomato intake, prostate cancer is the most widely researched. Although randomized controlled trial data are less available than observation data, a small number of dietary intervention trials using processed tomato products have been conducted. The results have been relatively successful as measured by improvements in prostate-specific antigen concentrations $[161,163,174-176]$ or increased apoptotic cell death in carcinomas [165]. A prostate cancer risk reduction of nearly $35 \%$ was ob- served when the test subjects consumed ten or more servings of tomato products per week and the effect was much stronger for subjects with more aggressive and advanced stages of cancer [177]. People consuming diets rich in tomato and tomato based products, which are rich in the carotenoid lycopene were found to be less likely to develop stomach and rectal cancers than those who consume lesser amounts of lycopene rich vegetables [178].

Tomatoes, with their distinctive nutritional attributes may play also an important role in reducing the risk of cardiovascular and associated diseases through their bioactivity in modulating disease process pathways. In 2004, Sesso et al. [152] reported an inverse association for women consuming greater intakes ( $>7$ servings per week) of tomato-based products and cardiovascular disease; an association not observed with lycopene intake alone. Several hypotheses are being tested related to the antioxidant properties of lycopene and a combination of carotenoids with coexisting water-soluble constituents delivered by tomatoes, such as vitamin $\mathrm{C}$. The antioxidant capacity of plasma decreases when tomatoes and tomato products are removed from the diet and increased when they are added back [164]. Consuming tomato products daily for 2 to 4 weeks increases antioxidant enzyme defenses and has been shown to reduce plasma lipid peroxides and the susceptibility of low density lipoprotein to oxidation $[159,166,179]$. Oxidative modification of low density lipoprotein is a key step in the development of atherosclerotic lesions [180]. Consuming diets with appreciable amounts of antioxidants from plant foods, such as tomatoes, to inhibit the oxidative process of low density lipoprotein may be one way to reduce the risk of cardiovascular atherosclerotic disease. One study $(n=60)$ in relatively healthy individuals [164] and 2 studies $(\mathrm{n}=$ 40 and $\mathrm{n}=57$ ) in individuals with type 2 diabetes, who are in a relatively pro-oxidant state, showed decreased lipid peroxidation rates [181] and decreased susceptibility of low-density lipoproteins to oxidation [159] after daily consumption of tomatoes or tomato juice. Others have reported less susceptibility to oxidation of DNA $[182,183]$ and low density lipoprotein [184] after tomato product consumption delivering approximately half (or more) of the lycopene dose typically used in lycopene supplementation studies. These data suggest that the health benefits of tomato/tomato product consumption are not solely because of lycopene content, but rather the result of the combination of nutrients and bioactive constituents delivered when the whole food is consumed.

Tomatoes and tomato products are also being investigated for possible anti-inflammatory, antithrombotic, and lipid-lowering effects. Supplementation of a low tomato diet with tomato products produces mixed results as measured by changes in inflammatory markers such as C-reactive protein (CRP), interleukin-6, and tumor ne- 
crosis factor-a. Jacob et al. [171] reported decreased CRP after a 2-week tomato juice supplementation containing approximately $21 \mathrm{mg}$ lycopene and 2 levels of vitamin $\mathrm{C}$ (45.5 mg and $435 \mathrm{mg}$, respectively). Both juices reduced CRP as well as total cholesterol concentration. Natural antithrombotic agents that influence platelet function or fibrinolytic activity are of interest as primary and seconddary cardiopreventive strategies. Aqueous extracts from tomatoes have been shown to display antiplatelet activity in vitro [185]. Subsequent research in humans shows significant reductions in ex vivo platelet aggregation 3 hours after supplementation with tomato extract from the yellowish membrane surrounding seeds in amounts equivalent to 2 or 6 fresh tomatoes [185].

For skin protection, tomato intake (40 g tomato paste corresponding to a lycopene dose of approximately 16 $\mathrm{mg}$ ) for more than 8 weeks reduced ultraviolet light-induced erythema $[168,169,186]$. Epidemiological studies suggest a beneficial relationship between dietary sources of lycopene and bone mass [187-189]. Likewise, lower serum lycopene concentrations have been documented in osteoporotic women compared with controls $[153,156]$. Rao et al. [155] have also reported an inverse association between serum lycopene and markers of oxidative stress and bone turnover in 33 postmenopausal women aged 50 to 60 years. Research for a possible role of tomatoes in brain health has largely been limited to case-control studies investigating the relationship between plasma/ serum lycopene and oxidative stress markers in people with documented Alzheimer's disease, Parkinson's disease, vascular dementia, and mild cognitive impairment compared with control/noncognitively impaired individuals. In general, plasma/serum lycopene concentrations are lower in cognitively impaired compared with control individuals [149-151,190], and oxidative stress markers are elevated and inversely correlated with plasma carotenoids concentrations $[150,151,191]$.

\subsubsection{Potato}

Potato ranks as the third most important food crop after wheat and rice. Potatoes yield on average more food energy on a per-hectare and a per-day basis than either cereals or cassava. In general, potato is perceived only as a source of carbohydrates, but is also an excellent source of essential amino acids. The predominant form of this carbohydrate is starch. A small but significant portion of this starch is resistant to digestion by enzymes in the stomach and small intestine, and so reaches the large intestine essentially intact. This resistant starch is considered to have similar physiological effects and health benefits as dietary fiber: it provides bulk, offers protecttion against colon cancer, improves glucose tolerance and insulin sensitivity, lowers plasma cholesterol and triglyceride concentrations, increases satiety, and possi- bly even reduces fat storage [192-194]. The amount of resistant starch in potatoes depends much on preparation methods. Cooking and then cooling potatoes significantly increases resistant starch. For example, cooked potato starch contains about $7 \%$ resistant starch, which increases to about $13 \%$ upon cooling [195]. Due to carbohydrate content, potatoes are considered to make a person obese if used in excess i.e. more than RDA of carbohydrates and fats. Recent research by the University of California, Davis and the National Center for Food Safety and Technology, Illinois Institute of Technology demonstrates that people can include potatoes in their diet and still lose weight [196]. Potatoes are also often broadly classified as high on the glycemic index (GI) and so are often excluded from the diets of individuals trying to follow a low-GI diet. In fact, the GI of potatoes can vary considerably depending on type (such as red, russet or white), origin (where it was grown), preparation methods (i.e., cooking method, whether it is eaten hot or cold, whether it is mashed or cubed or consumed whole, etc.), and with what it is consumed (i.e., the addition of various high-fat or high-protein toppings) [197]. Potato contains a small amount of protein (less than $6 \%$ ), but the biological value of potato protein is the best among vegetable sources and comparable to cow's milk. Human feeding trials suggested that potato proteins are of a very high quality, possibly because they are rich in essential amino acids, such as lysine, and other metabolites, which may enhance protein utilization [198-200]. The lysine content of potato complements cereal-based diets, which are deficient in this amino acid.

In addition to high quality proteins, potato tubers accumulate significant amounts of vitamins and minerals, as well as an assortment of phytochemicals including phenolics, phytoalexins, and protease inhibitors. Chlorogenic acid constitutes up to $90 \%$ of the potato tuber natural phenols. Others found in potatoes are 4-O-caffeoylquinic acid (crypto-chlorogenic acid), 5-O-caffeoylquinic (neo-chlorogenic acid), 3,4-dicaffeoylquinic and 3,5-dicaffeoylquinic acids [201]. A medium-size 150 $\mathrm{g}$ potato with the skin provides $27 \mathrm{mg}$ of vitamin C $(45 \%$ of the daily allowance), $620 \mathrm{mg}$ of potassium (18\% of daily allowance), $0.2 \mathrm{mg}$ vitamin B6 (10\% of daily allowance) and trace amounts of thiamin, riboflavin, folate, niacin, magnesium, phosphorus, iron, and zinc. The fiber content of a potato with skin $(2 \mathrm{~g})$ is equivalent to that of many whole grain breads, pastas, and cereals.

Potato contributes a small but significant amount of phytochemicals. Several yellow, red, and purple fleshed types with high phytochemical content have recently been introduced into the market. The purple potato has purple skin and flesh, which becomes blue once cooked. A mutation in the varieties' $P$ locus causes production of the antioxidant anthocyanin [202]. Total phenolics in 
potato tubers range in concentration from 0.5 to $1.7 \mathrm{~g} / \mathrm{kg}$ [203,204]. Al-Saikhan et al. [205] reported significant differences in total phenolics among cultivars, with flesh color having no significant effect on total phenolics. Nearly $50 \%$ of the total phenolic compounds in potato are located in the peel and adjoining tissue, but decrease toward the center of the tuber $[205,206]$, with chlorogenic acid representing about 90 percent of the total polyphenolic content [201].

Potato tubers contain a moderate amount of vitamin C, in the range of about 10 to $104 \mathrm{mg} / \mathrm{kg}$, depending on the cultivar and the growing season, but it declined rapidly (30 to 50 percent) during storage and cooking [199,207, 208]. Other antioxidants found in potato include 0.5 to $2.8 \mathrm{mg} / \mathrm{kg} \alpha$-tocopherol, 0.13 to $0.6 \mathrm{mg} / \mathrm{kg}$ lutein, and 1 $\mathrm{mg} / \mathrm{kg} \beta$-carotene [209-211]. Cao et al. [66] estimated the total antioxidant capacity of potato to be in the medium range among 22 commonly consumed vegetables. Potato also contributes a small amount of selenium (0.01 $\mathrm{mg} / \mathrm{kg})$ and folate $(0.35 \mathrm{mg} / \mathrm{kg})$ to the human diet [68, 212].

\subsubsection{Sweet and Hot Peppers}

Peppers come in a beautiful array of colors and shapes. They add flavor, color, and crunch to many low-calorie dishes. All fresh peppers are excellent sources of vitamins C, K, carotenoids, and flavonoids [213]. Antioxidant vitamins $\mathrm{A}$ and $\mathrm{C}$ help to prevent cell damage, cancer, and diseases related to aging, and they support immune function. They also reduce inflammation like that found in arthritis and asthma. Vitamin K promotes proper blood clotting, strengthens bones, and helps protect cells from oxidative damage. Red peppers are a good source of lycopene, which is earning a reputation for helping to prevent prostate cancer as well as cancer of the bladder, cervix, and pancreas. Beta-cryptoxanthin, another carotenoid in red peppers, is holding promise for helping to prevent lung cancer related to smoking and secondhand smoke. Besides being rich in phytochemicals, peppers provide a decent amount of fiber. Significant differences in vitamin $\mathrm{C}$ were observed between cultivars, but not between species. On average, fruits contain between 1 to $2 \mathrm{~g} / \mathrm{kg}$ vitamin C, which is equivalent to $200 \%$ to $300 \%$ of the recommended daily allowance for adult men and women [214]. The level of provitamin A carotenoids $(\alpha-$ and $\beta$-carotene) is cultivar specific. Some cultivars of hot pepper have as much as $12 \mathrm{mg} / \mathrm{kg}$ total carotenoids, while others are bellow the detectable level $[214,215]$. Major flavonoids in the peppers are quercetin and luteolin. They are present in conjugated form and their content varies among cultivars ranging from not detectable to $800 \mathrm{mg} / \mathrm{kg}$ [216]. When comparing the nutrient values of the different bell peppers, studies have shown that red bell peppers have significantly higher levels of nutrients than green. Red bell peppers also contain lycopene, which helps to protect against cancer and heart disease. Possibly due to their vitamin $\mathrm{C}$ and beta carotene content, bell peppers have been shown to be protective against cataracts. Just like other nutrient-dense vegetables, bell peppers contain many different powerful phytochemicals. Bell peppers have also been shown to prevent blood clot formation and reduce the risk of heart attacks and strokes probably due to their content of substances such as vitamin C, capsaicin, and flavonoids. Although chili hot peppers contain a higher amount of those substances, bell peppers should still be promoted especially for individuals with elevated cholesterol levels.

Hot peppers don't have that spicy image for nothing. The major phytochemicals in hot peppers are capsaicinnoids. More than 20 capsaicinoids, belonging to two groups, capsaicin and dihydrocapsaicin, have been identified in pepper. Capsaicin was discovered in 1846 and its structure, as an acid amide, was elucidated by Nelson [217]. Capsaicin constitutes about $70 \%$ of the pungent flavour in hot pepper, while its analogue dihydrocapsaicin represents $30 \%$ [218]. The two groups differ in the presence or absence of double bonds in the fatty acid side-chain and within each group they differ in the length and branching point in the fatty acid side-chain [219]. Significant variations in the profile of capsaicinoids are found between and within pepper species, ranging from about 220 ppm (3400 Scoville Heat Units, SHU) in Capsicum annum to 20,000 ppm (320,000 SHU) in Capsicum chinense [220]. Hot peppers' fire comes from capsaicin, which acts on pain receptors, not taste buds, in our mouths. Capsaicin predominates in the white membranes of peppers, imparting its "heat" to seeds as well. The capsaicin in hot peppers has been shown to decrease blood cholesterol and triglycerides, boost immunity, and reduce the risk of stomach ulcers. It used to be thought that hot peppers aggravated ulcers. Instead, they may help kill bacteria in the stomach that can lead to ulcers. Capsaicin has also analgesic, anti-bacterial, and antidiabetic properties. Capsaicin is an ingredient in several commercial formulations formulation for the treatment of muscle pains, toothaches, burning-mouth syndrome, gastric ulceration, painful diabetic neuropathy, postmastectomy pain syndrome, and osteo- and rheumatoid-arthritis. It is also prescribed for bladder hypersensivity, vasomotor rhinitis, and hyperreflexia of spinal origin [221].

Chilli hot peppers have amazingly high levels of vitamins and minerals. Just $100 \mathrm{~g}$ provides (in \% of recommended daily allowance), $240 \%$ of vitamin $\mathrm{C}$ (ascorbic acid), $39 \%$ of vitamin B6 (pyridoxine), $32 \%$ of vitamin A, $13 \%$ of iron, $14 \%$ of copper, $7 \%$ of potassium [222]. Fresh chili hot peppers, red or green, are rich source of vitamin-C. $100 \mathrm{~g}$ fresh chilies provide about $143.7 \mu \mathrm{g}$ or about $240 \%$ of recommended daily allowance. Chillies 
are also good in B-complex group of vitamins such as niacin, pyridoxine (vitamin B6), riboflavin and thiamin (vitamin B1). These vitamins are essential in the sense that body requires them from external sources to replenish. Chilli hot peppers contain good amount of minerals like potassium, manganese, iron, and magnesium. Potassium in an important component of cell and body fluids that helps controlling heart rate and blood pressure. Manganese is used by the body as a co-factor for the antioxidant enzyme superoxide dismutase.

Both hot and sweet peppers contain substances that have been shown to increase the body's heat production and oxygen consumption for about 20 minutes after eating. This is great news; it means our body is burning extra calories, which helps weight loss.

\subsubsection{Eggplant}

The eggplant, known as aubergine in Europe and brinjal in south Asia, is a popular vegetable cop grown in many countries throughout the subtropics, tropics and Mediterranean area, since it requires a relatively long season of warm weather to give good yields. In addition to featuring a host of vitamins and minerals, eggplant also contains important phytochemicals which have antioxidant activity. Phytochemicals contained in eggplant include phenolic compounds, such caffeic and chlorogenic acid, and flavonoids, such as nasunin. Nasusin or delphinidin3-(coumaroylrutinoside)-5-glucoside is the major phytochemical in eggplant. Nasunin is part of the anthocyanin purple pigment found in the peel of eggplant, purple radish, red turnip, and red cabbage [223-225]. Matsuzoe et al. [226] examined the profile of anthocyanins in several eggplant cultivars and found that nasunin represents between $70 \%$ to $90 \%$ of the total anthocyanins in the peel, however the actual concentration of nasunin has not been reported. Nasunin is an antioxidant that effectively scavenges reactive oxygen species, such as hydrogen peroxide, hydroxyl and superoxide, as well as inhibits the formation of hydroxyl radicals, probably by chelating ferrous ions in the Fenton reaction [223,225].

By chelating iron, nasunin lessens free radical formation with numerous beneficial results, including protecting blood cholesterol from peroxidation; preventing cellular damage that can promote cancer; and lessening free radical damage in joints, which is a primary factor in rheumatoid arthritis. The predominant phenolic compound found in all culticars tested is chlorogenic acid, which is one of the most potent free radical scavengers found in plant tissues [226]. Benefits attributed to chlorogenic acid include antimutagenic (anti-cancer), antimicrobial, anti-low density lipoproteins (bad cholesterol) and antiviral activities. Whitaker and Stommel [226] studied seven eggplant cultivars grown comercially in the United States and a diverse collection of exotic and wild eggplants from other counties. In addition to chlorogenic acid, they found 13 other phenolic acids present at significantly varying levels in the commercial cultivars, although chlorogenic acid was the predominant phenolic compound in all of them. "Black Magic" a commercial eggplant cultivar representative of US market types was found to have nearly three times the amount of antioxidant phenolics as the other eggplant cultivars that were studied. In addition to their nutritive potential, the phenolic acids in eggplant are responsible for some eggplants' bitter taste and the browing that results when their flesh is cut. The enzyme polyphenol oxidase triggers a phenolic reaction that produces the brown pigments. Breeders have begun work on developing eggplant cultivars with an optimal balance of phenolics to ensure both optimal nutritional value and pleasing taste.

Eggplant fruits also contain several other antioxidants including the carotenoids lycopene, lutein, and $\alpha$-carotene, as well as the flavonoids myricetin and kaempferol [77,227]. Total antioxidant activity of eggplant was estimated to be about $190 \mu \mathrm{mol}$ Trolox equivalent per $40 \mathrm{~g}$ serving size, which ranks it in the middle among 22 commonly consumed vegetables [66]. Eggplant is an excellent source of digestion-supportive dietary fiber and bone-building manganese. It is very good source of enzyme-catalyzing molybdenum and heart-healthy potassium. Eggplant is also a good source of bone-building vitamin $\mathrm{K}$ and magnesium as well as heart-healthy copper, vitamin C, vitamin B6, folate, and niacin [228,229].

Studies have shown that eggplant is effective in the treatment of high blood cholesterol [230]. Guimarães et al. [231] showed a significant decrease in blood levels of low-density lipoproteins and total cholesterol in human Vol.unteers who were fed with eggplant powder. A study from Heart Institute of the University of São Paulo (Brazil) found no effects at all and does not recommend eggplant as a replacement to statins [232]. Another study showed that eggplant extract inhibited human fibrosarcoma HT-180 cell invasiveness [233]. Kwon et al. [234] presented eggplant phenolics as inhibitors of key enzymes relevant fot type 2 diabetes and hypertension.

Eggplant is richer in nicotine than any other edible vegetable, with a concentration of $100 \mathrm{ng} / \mathrm{g}$ (or 0.01 $\mathrm{mg} / 100 \mathrm{~g}$ ). However, the amount of nicotine from eggplant or any other food is negligible compared to passive smoking [235]. On average, $9 \mathrm{~kg}$ of eggplant contains about the same amount of nicotine as a cigarette. Eggplant is also among a small number of vegetables that contain measurable amounts of oxalates. When oxalates become too concentrated in body fluids, they can crystalize and cause health problems such as kidney calcium oxalate stones. For this reason, individuals with already existing and untreated kidney or gallbladder problems 
may want to avoid eating eggplant [236,237]. Laboratory studies have shown that oxalates may also interfere with absorption of calcium from the body [238].

\section{Conclusions}

Regular consumption of a vegetable rich diet has undeniable positive effects on health since phytonutriceuticals of vegetables can protect the human body from several types of chronic diseases. The mechanism by which vegetables decrease risk of disease is complex and largely unknown. Various components of the whole food are likely to contribute to the overall health benefit. Various phytonutriceuticals with antioxidant properties may work directly by quenching free radicals or indirectly by participating in cell signaling pathways sensitive to redox balance. Nutrients such as potassium contribute to blood pressure regulation. The dietary fiber content and type of different vegetables may also contribute to the overall health benefit, such as improving bowel transit, lowering cholesterol, helping manage blood glucose concentrations, and by transporting a significant amount of minerals and phytochemicals linked to the fibre matrix through the human gut. Finaly, increasing vegetables in the diet may reduce the intake of saturated fats, trans fats, and foods with higher caloric density, all of which may be related to a healthier overall diet. Because each vegetable contains a unique combination of phytonutriceuticals (vitamins, minerals, dietary fiber and phytochemicals), a great diversity of vegetables should be eaten to ensure that individual's diet includes a combination of phytonutriceuticals and to get all the health benefits. The availability of a large diversity of vegetables year-round, allied to increase in mean per capita incomes in recent years and knowledge of vegetable health benefits, have enable consumers to include a variety of health promoting phytonutriceuticals in their diet.

Nutritional quality as understood by the consumers and available at a moderate price may encourage enhanced consumption, thereby conferring an important marketing incentive to plant breeding. Research on the health benefits of vegetables, from a horticultural and breeding perspective, needs to focus on key areas in the near future such as: 1) to continue the evaluation of phytonutriceuticals content among older versus newer major cultivars; 2) to identify the genetic mecanisms that regulate the syntesis of their key phytochemicals, such as the glucosinolates, thiosulfides and flavonoids, in order to develop cultivars rich in a variety of phytochemicals and in order to ensure that a mixture of phytochemicals enters into the human diet; 3 ) to study the potencial change in the balance of these compounds (and their eventual synergisms or interactions); and 4) to identify the optimum conditions for mantaining these phytochemicals after harvest and processing since studies have shown that the biovailability of some of the phytochemicals increase dramatically after storage and processing and others degrade rapidly.

\section{REFERENCES}

[1] B. Quebedeaux and H. M. Eisa, "Horticulture and Human Health: Contributions of Fruits and Vegetables," Proceedings of the 2nd International Symposium Horticulture and Human Health HortScience, Vol. 25, 1990, pp. 1473-1532.

[2] W. Craig and L. Beck, "Phytochemicals: Health Protective Effects," Canadian Journal of Dietetic Practice and Research, Vol. 60, No. 2, 1999, pp. 78-84.

[3] M. J. Wargovich, "Anticancer Properties of Fruits and Vegetables," Hort Science, Vol. 35, 2000, pp. 573-575.

[4] J. S. Dias and E. Ryder, "World Vegetable Industry: Production, Breeding, Trends," Hort Review, Vol. 38, 2011, pp. 299-356.

[5] S. Southon, "Increased Fruit and Vegetable Consumption within the EU: Potential Health Benefits," Food Research International, Vol. 33, No. 3-4, 2000, pp. 211-217. doi:10.1016/S0963-9969(00)00036-3

[6] E. Herrera, R. Jimenez, O. I. Aruoma, S. Hercberg, I. Sanchez-Garcia and C. Fraga, "Aspects of Antioxidant Foods and Supplements in Health and Disease," Nutrition Reviews, Vol. 67, No. 1, 2009, pp. S140-S144. doi:10.1111/j.1753-4887.2009.00177.x

[7] R. L. Prior and G. Cao, "Antioxidant Phytochemicals in Fruit and Vegetables, Diet and Health Implications," HortScience, Vol. 35, No. 4, 2000, pp. 588-592.

[8] D. Hyson, "The Health Benefits of Fruit and Vegetables: A Scientific Overview for Health Professionals," Produce for Better Health Foundation, Wilmington DE, 2002.

[9] G. Golberg, "Plants: Diet and Health," In: G. Golberg, Ed., The Report of a British Nutrition Foundation Task Force, Blackwell Science, Oxford, 2003, pp. 152-163.

[10] IFAVA, "Fruit, Vegetables and Health: A Scientific Overview," 2006. http://www.5aday.co.nz/5adaywebsite/cms_resources/file /Scientific20\%Overview

[11] J. D. H. Keatinge, F. Waliyar, R. H. Jammadass, A. Moustafa, M. Andrade, P. Drechsel, J. D’A. Hughes, P. Kardivel and K. Luther, "Re-Learning Old Lessons for the Future of Food: By Bread Alone No Longer-Diversifying Diets with Fruit and Vegetables," Crop Science, Vol. 50, No. 1, 2010, pp. 51-62. doi:10.2135/cropsci2009.09.0528

[12] P. Mullie and P. Clarys, "Association between Cardiovascular Disease Risk Factor Knowledge and Lifestyle," Food and Nutrition Science, Vol. 2, No. 10, 2011, pp. 1048-1053. doi:10.4236/fns.2011.210140

[13] J. S. Dias, "World Importance, Marketing and Trading of Vegetables," Acta Horticulturae, Vol. 921, 2011, pp. 153-169. 
[14] S. J. Kays. and J. S. Dias, "Common Names of Commercially Cultivated Vegetables of the World in 15 Languages," Economic Botany, Vol. 49, No. 2, 1995, pp. 115-152. doi:10.1007/BF02862917

[15] S. J. Kays, "Cultivated Vegetables of the World: A Multilingual Onomasticon," Wageningen Academic Publishers, The Netherlands, 2011. doi:10.3920/978-90-8686-720-2

[16] Monsanto, "Supplemental Toolkit for Investors," Monsanto, 2011.

[17] S. E. Nielsen, J. F. Young, B. Daneshvar, S. T. Lauriden, P. Knuthsen, B. Sandrstromand and L. O. Dragsted, "Effect of Parsley (Petroselinum crispum) Intake on Urinary Apigenin Excretion, Blood Antioxidant Enzymes and Biomarkers for Oxidative Stress in Human Subjects," British Journal of Nutrition, Vol. 81, No. 6, 1999, pp. 447-455.

[18] L. S. Ching and S. Mohamed, "Alpha-Tocopherol Content of 62 Edible Tropical Plants," Journal of Agriculture and Food Chemistry, Vol. 49, No. 6, 2001, pp. 3101-3105. doi:10.1021/if000891u

[19] M. A. Lila, "Anthocyanins and Human Health: An in Vitro Investigative Approach," Journal of Biomedicine and Biotechnology, Vol. 2004, No. 5, 2004, pp. 306-313. doi:10.1155/S111072430440401X

[20] M. Horbowicz, R. Kosson, A. Grzesiuk and H. D. Bski, "Anthocyanins of Fruits and Vegetables-Their Occurrence Analysis and Role in Human Nutrition," Vegetable Crops Research Bulletin, Vol. 68, No. 1, 2008, pp. 5-22. doi:10.2478/v10032-008-0001-8

[21] P. W. Simon and I. L. Goldman, "Carrot," In: R. J. Sing, Ed., Genetic Resources, Chromosome Engineering, and Crop improvement, CRC Press, Boca Raton, 2007, pp. 497-516.

[22] A. Crozier, J. Burns, A. Aziz, A. J. Stewart, H. S. Rabiasz, G. I. Jenkins, C. A. Edwards and M. E. J. Lean, "Antioxidant Flavonols from Fruits, Vegetables and Beverages: Measurements and Bioavailability," Biological Research, Vol. 33, No. 2, 2000, pp. 79-88. doi: $10.4067 / \mathrm{S} 0716-97602000000200007$

[23] D. Almeida, "Manual de Culturas Hortícolas," Vol. 1, Editorial Presença, Lisboa, 2006.

[24] N. P. S. Dhillon, A. J. Monforte, M. Pitrat, S. Pandey, P. K. Singh, K. R. Reitsma, J. Garcia-Mas, A. Sharma and J. M. McCreight, "Melon Landraces of India: Contributions and Importance," Plant Breeding Reviews, Vol. 35, 2012, pp. 85-150.

[25] Y. Burger, Y. Yeselson, U. Saar, H. S. Paris, N. Katzir, Y. Tadmor and A. A. Schaffer, "Screening of Melon (Cucumis melo) Germplasm for Consistently High Sucrose Content and for High Ascorbic Acid Content," In: A. Lebeda and H. S. Paris, Eds., Progress in Cucurbit Genetics and Breeding Research, Palacky University, Olomouc, 2004, pp. 151-155.

[26] K. M. Crosby, G. E. Lester and D. I. Leskovar, "Genetic Variation for Beneficial Phytochemical Levels in Melons (Cucumis melo)," In: G. J. Holmes, Ed., Cucurbitaceae 2006, Universal Press, Raleigh, 2006, pp. 70-76.

[27] J. Scott, F. Releille and J. Fletcher, "Folic Acid and
Folates: The Feasibility for Nutricional Enhancement in Plant Foods," Journal of the Science and Food Agriculture, Vol. 80, No. 7, 2000, pp. 795-824. doi:10.1002/(SICI) 1097-0010(20000515)80:7<795::AIDJSFA599 $>3.0 . \mathrm{CO} ; 2-\mathrm{K}$

[28] T. He, C. Y. Huang, H. Chen and Y. H. Hou, "Effects of Spinach Powder Fat-Soluble Extract on Proliferation of Human Gastric Adenocarcinoma Cell," Biomedical Environmental Science, Vol. 12, No. 4, 1999, pp. 247-252.

[29] D. Prakash, P. Nath and M. Pal, "Composition, Variation of Nutritional Contents in Leaves, Seed Protein, Fat and Fatty Acid Profile of Chenopodium Species," Journal of the Science and Food Agriculture, Vol. 62, No. 2, 1993, pp. 203-205. doi:10.1002/jsfa.2740620214

[30] R. Sienera, "Oxalate Contents of Species of the Polygonaceae, Amaranthaceae and Chenopodiaceae Families," Food Chemistry, Vol. 98, No. 2, 2006, pp. 220-224. doi:10.1016/j.foodchem.2005.05.059

[31] S. K. Misra, "Anti-Nutritive Bioactive Compounds Present in Unconventional Pulses and Legumes," The Research Journal of Pharmaceutical, Biological and Chemical Sciences, Vol. 3, 2012, pp. 586-597.

[32] A. C. Mallillin, T. P. Trinidad, R. Raterta, K. Dagbay and A. S. Loyola, "Dietary Fibre and Fermentability Characteristics of Root Crops and Legumes," British Journal of Nutrition, Vol. 100, No. 3, 2008, pp. 485-488. doi:10.1017/S000711450891151X

[33] T. P. Trinidad, A. C. Mallillin, A. S. Loyola, R. S. Sagum and R. R. Encabo, "The Potential Health Benefits of Legumes as a Good Source of Dietary Fibre," British Journal of Nutrition, Vol. 103, No. 4, 2010, pp. 569-574. doi:10.1017/S0007114509992157

[34] World Cancer Research Fund, "Food, Nutrition and the Prevention of Cancer: A Global Perspective," American Institute for Cancer Research, Washington DC, 1997.

[35] D. T. H. Verhoeven, R. A. Goldbohm, G. Van Poppel, H. Verhagen and P. A. Van Den Brandt, "Epidemiological Studies on Brassica Vegetables and Cancer Risk," Cancer Epidemiology Biomarkers \& Prevention, Vol. 5, No. 9, 1996, pp. 733-751.

[36] C. B. Ambrosone, S. E. McCann, J. L. Freudenheim, J. R. Marshall, Y. Zhang and P. G. Shields, "Breast Cancer Risk in Premenopausal Women is Inversely Associated with Consumption of Broccoli: A Source of Isothiocyanates, but Is Not Modified by GST Genotype," The Journal of Nutrition, Vol. 134, No. 5, 2004, pp. 11341138 ,

[37] P. Brennan, C. C. Hsu, N. Moullan, N. Szeszenia-Dabrowska, J. Lissowska, D. Zaridze, P. Rudnai, E. Fabianova, D. Mates and V. Benckoet, "Effect of Cruciferous Vegetables on Lung Cancer in Patients Stratified by Genetic Status: A Mendelian Randomisation Approach," Lancet, Vol. 366, No. 9496, 2005, pp. 1558-1560. doi:10.1016/S0140-6736(05)67628-3

[38] V. A. Kirsh, U. Peters, S. T. Mayne, A. F. Subar, N. Chatterjee, C. C. Johnson and R. B. Hayes, "Prospective Study of Fruit and Vegetable Intake and Risk of Prostate Cancer," Journal of the National Cancer Institute, Vol. 99, No. 15, 2007, pp. 1200-1209. 
doi:10.1093/jnci/djm065

[39] M. Traka, "Broccoli Consumption Interferes with Prostate Cancer Progression: Mechanisms of Action," Acta Horticulturae, Vol. 867, No. 5, 2010, pp. 19-25.

[40] L. Kohlmeier and L. Su, "Cruciferous Vegetables Consumption and Colorectal Cancer Risk: Meta-Analysis of the Epidemiological Evidence," FSEB Journal, Vol. 11, 1997 , pp. 369.

[41] A. Seow, J. M. Yuan, C. L. Sun, D. Van Den Berg, H. P. Lee and M. C. Yu, "Dietary Isothiocyanates, Glutathione S-Transferase Polymorphisms and Colorectal Cancer Risk in the Singapore Chinese Health Study," Carcinogenesis, Vol. 23, No. 12, 2002, pp. 2055-2061. doi:10.1093/carcin/23.12.2055

[42] S. J. London, J. M. Yuan, F. L. Chung, Y. T. Gao, G. A. Coetzee, R. K. Ross and M. C. Yu, "Isothiocyanates, Glutathione S-transferase M1 and T1 Polymorphisms, and Lung-Cancer Risk: A Propective Study of Men in Shanghai, China," Lancet, Vol. 356, No. 9231, 2000, pp. 724-729. doi:10.1016/S0140-6736(00)02631-3

[43] J. H. Fowke, F. L. Chung, F. Jin, D. Qi, Q. Cai, C. Conaway, J. R. Cheng, X. O. Shu, Y. T. Gao and W. Zheng, "Urinary Isothiocyanate Levels, Brassica, and Human Breast Cancer," Cancer Research, Vol. 63, No. 14, 2003, pp. 3980-3986.

[44] M. A. Joseph, K. B. Moysich, J. L. Freudenheim, P. G. Shields, E. D. Bowman, Y. Zhamg, J. R. Marshall and C. B. Ambrosone, "Cruciferous Vegetables, Generic Polymorphism in Glutathione S-Transferases M1 and T1, and Protate Cancer Risk," Nutrition and Cancer, Vol. 50, 2004, pp. 206-213. doi:10.1207/s15327914nc5002 11

[45] N. Juge, R. F. Mithen and M. Traka, "Molecular Basis for Chemoprevention by Sulforaphane: A Comprehensive Review," Cellular and Molecular Life Science, Vol. 64, No. 9, 2007, pp. 1105-1127. doi:10.1007/s00018-007-6484-5

[46] M. W. Farnham, K. K. Stephenson and J. Fahey, "Capacity of Broccoli to Induce Mammalian Chemo Protective Enzyme Varies Among Inbred Lines," Journal of the American Society for Horticultural Science, Vol. 125, No. 4, 2000, pp. 482-488.

[47] J. W. Fahey, A. T. Zalcmann and P. Talalay, "The Chemical Diversity and Distribution of Glucosinolates and Isothiocyanates among Plants," Phytochemistry, Vol. 56, No. 1, 2001, pp. 5-51. doi:10.1016/S0031-9422(00)00316-2

[48] C. H. VanEtten, M. E. Dzenbichler, P. Williams and W. F. Kwolek, "Glucosinolates and Derived Products in Cruciferous Vegetables. Analysis in the Edible Part from Twenty-Two Varieties of Cabbage," Journal of Agriculture and Food Chemistry, Vol. 24, No. 3, 1976, pp. 452455. doi:10.1021/jf60205a049

[49] D. G. Carlson, M. E. Daxenbichler, C. H. Van Etten, H. L. Tookey and P. H. Williams, "Glucosinolates in Crucifer Vegetables: Turnip and Rutabagas," Journal of Agriculture and Food Chemistry, Vol. 29, No. 6, 1981, pp. 1235-1239. doi:10.1021/jf00108a034

[50] D. G. Carlson, M. E. Daxenbichler, C. H. VanEtten, C. B. Hill and P. H. Williams, "Glucosinolates in Radish Cul- tivars," Journal of the American Society for Horticultural Science, Vol. 110, No. 5, 1985, pp. 634-638.

[51] D. G. Carlson, M. E. Daxenbichler, C. H. VanEtten, W. F. Kwolek and P. H. Williams, "Glucosinolates in Crucifer Vegetables: Broccoli, Brussels Sprouts, Cauliflower, Collards, Kale, Mustard Green, and Kohlrabi," Journal of the American Society for Horticultural Science, Vol. 112, 1987, pp. 173-178.

[52] D. G. Carlson, M. E. Daxenbichler, C. H. VanEtten, W. F. Kwolek, C. B. Hill and P. H. Williams, "Glucosinolates in Turnip Tops and Roots: Cultivars Grown for Greens and/or Roots," Journal of the American Society for Horticultural Science, Vol. 112, No. 1, 1987, pp. 179-183.

[53] M. K. Kushad, A. F. Brown, A. C. Kurillicn, J. A. Juvik, B. P. Klein, M. A. Wallig and E. H. Jeffery, "Variation in Glucosinolates in Vegetable Crops of Brassica oleracea," Journal of Agriculture and Food Chemistry, Vol. 47, No. 4, 1999, pp. 1541-1548. doi:10.1021/jf980985s

[54] E. Ciska, B. Martyniak-Przybyszewska and H. H. Kozlowska, "Content of Glucosinolates in Cruciferous Vegetables Grown at the Same Site for Two Years under Different Climatic Condition," Journal of Agriculture and Food Chemistry, Vol. 48, No. 7, 2000, pp. 2862-2867. doi:10.1021/jf981373a

[55] F. Vallejo, F. A. Tomas-Barberan and C. Garcia-Viguera, "Potential Bioactive Compounds in Health Promotion from Broccoli Cultivars Grown in Spain," Journal of the Science and Food Agriculture, Vol. 82, No. 11, 2002, pp. 1293-1297. doi:10.1002/jsfa.1183

[56] F. Vallejo, F. A. Tomas-Barberan, A. G. Banavent-Garcia and C. Garcia-Viguera, "Total and Individual Glucosinolate Contents in Inflorescences of Eight Broccoli Cultivars Grown under Various Climatic and Fertilization Conditions," Journal of the Science and Food Agriculture, Vol. 83, No. 4, 2003, pp. 307-313. doi:10.1002/jsfa.1320

[57] J. Nilsson, K. Olsson, G. Engqvist, J. Ekvall, M. Olsson, M. Nyman and B. Åkesson, "Variation in the Content of Glucosinolates, Hydroxycinnamic Acids, Carotenoids, Total Antioxidant Capacity and Low-Molecular-Weight Carbohydrates in Brassica Vegetables," Journal of the Science and Food Agriculture, Vol. 86, No. 4, 2006, pp. 528-538. doi:10.1002/jsfa.2355

[58] J. Borkowski, A. Szajdek, E. J. Borkowska, E. Ciska and H. Zielinski, "Content of Selected Bioactive Components and Anti-Oxidant Properties of Broccoli (Brassica oleracea L.)," European Food Research and Technology, Vol. 226, No. 3, 2008, pp. 459-465. doi:10.1007/s00217-006-0557-9

[59] M. E. Cartea, P. Velasco, S. Obregón, G. Padilla and A. de Haro, "Seasonal Variation in Glucosinolate Content in Brassica oleracea Crops Grown in Northwestern Spain," Phytochemistry, Vol. 69, No. 2, 2008, pp. 403-410. doi:10.1016/j.phytochem.2007.08.014

[60] M. Hansen, G. B. Bengtsson, G. I. Borge, L. Berge and A. B. Wold, "Red Cabbage, a Vegetable Rich in Health-Related Glucosinolates," Acta Hort, Vol. 867, No. 5, 2010, pp. 61-65.

[61] J. W. Fahey, Y. S. Zhang and P. Talalay, "Broccoli sprouts: An Exceptionally Rich Source of Inducers of 
Enzymes that Protects against Chemical Carcinogens," Proceedings of National, Academic Science (USA), Vol. 94, No. 19, 1997, pp. 10367-10372. doi:10.1073/pnas.94.19.10367

[62] R. M. Goodrich, J. L. Anderson and G. Stoewsand, "Glucosinolate Changes in Blanched Broccoli and Brussels Sprouts," Journal of Food Processing and Preservation, Vol. 13, No. 4, 1989, pp. 275-280. doi:10.1111/j.1745-4549.1989.tb00106.x

[63] B. Kusznierewics, A. Bartoszek, L. Wolska, J. Drzewiwcki, S. Gorinstein and J. Namiesnik, "Partial Characterization of White Cabbages (Brassica oleracea var. capitata f. alba) from Different Regions by Glucosinolates, Bioactive Compounds, Total Antioxidant Activities and Proteins," LWT-Food Science and Technology, Vol. 41, No. 1, 2008, pp. 1-9. doi:10.1016/j.lwt.2007.02.007

[64] R. Magrath and R. Mithen, "Maternal Effects of the Expression of Individual Aliphatic Glucosinolates in Seeds and Seedlings of Brasscia napus," Plant Breeding, Vol. 111, No. 3, 1993, pp. 249-252. doi:10.1111/j.1439-0523.1993.tb00637.x

[65] R. Magrath, F. Bano, M. Morgner, I. Parkin, A. Sharpe, C. Lister, C. Dean, J. Turner, D. Lydiate and R. Mithen, "Genetics of Aliphatic Glucosinolates I. Side Chain Elongation in Brassica napus and Arabidopsis thaliana," Heredity, Vol. 72, No. 3, 1994, pp. 290-299. doi:10.1038/hdy.1994.39

[66] A. Giamoustraris and R. Mithen, "Genetics of Aliphatic Glucosinolates. 4. Side-Chain Modification in Brassica oleracea," Theoretical and Applied Genetics, Vol. 93, No. 5-6, 1996, pp. 1006-1010. doi:10.1007/BF00224105

[67] G. Cao, E. Sofic and R. L. Prior, "Antioxidant Capacity of Tea and Common Vegetables," Journal of Agriculture and Food Chemistry, Vol. 44, No. 11, 1996, pp. 3426-3431. doi:10.1021/jf9602535

[68] A. Kurilich, G. J. Tsau, A. Brown, L. Howard, B. Klein, E. Jeffery, M. M. Kushad, M. A. Wallig and J. A. Juvik, "Carotene, Tocopherol and Ascorbate Contents in SubSpecies of Brassica oleracea," Journal of Agriculture and Food Chemistry, Vol. 47, 1999, pp. 1576-1581. doi:10.1021/jf9810158

[69] E. J. M. Konings, H. H. Roomans, E. Dorant, R. A. Goldbohm, W. H. Saris and P. A. van den Brandt, "Folate Intake of the Dutch Population According to Newly Established Liquid Chromatography Data for Foods," The American Journal of Clinical Nutrition, Vol. 73, No. 4, 2001, pp. 765-776.

[70] A. Fermenia, R. R. Selvendran, S. G. Ring and J. A. Robertson, "Effects of Heat Treatment and Dehydration on Properties of Cauliflower Fiber," Journal of Agriculture and Food Chemistry, Vol. 47, No. 2, 1999, pp. 728-732. doi:10.1021/jf980462k

[71] C. R. Rahn, G. D. Bending, R. D. Lillywhite and M. K. Turner, "Chemical Characterisation of Vegetable and Arable Crops Residue Materials: A Comparison of Methods," Journal of the Science and Food Agriculture, Vol. 79, 1999, pp. 1715-1721. doi:10.1002/(SICI)1097-0010(199909)79:12<1715::AID-

\section{JSFA426>3.0.CO;2-V}

[72] G. Banuelos and D. Meek, "Selenium Accumulation in Selected Vegetables," Journal of Plant Nutrition, Vol. 12, No. 10, 1989, pp. 1255-1272. doi:10.1080/01904168909364034

[73] J. W. Finley, C. Ip, D. J. Lisk, C. D. Davis, K. J. Hintze, and P. D. Whanger, "Cancer-Protective Properties of HighSelenium Broccoli," Journal of Agriculture and Food Chemistry, Vol. 49, No. 5, 2001, pp. 2679-2683. doi:10.1021/jf0014821

[74] X. Cai, E. Block, P. C. Uden, X. Zhang, B. D. Quimby and J. J. Sullivan, "Allium Chemistry: Identification of Selenoaminoacids in Ordinary and Selenium-Enriched Garlic, Onion and Broccoli Using Gas Chromatography with Atomic Emission Detection," Journal of Agriculture and Food Chemistry, Vol. 43, No. 7, 1995, pp. 1754-1757. doi:10.1021/jf00055a002

[75] J. W. Finley, C. D. Davis and Y. Feng, "Selenium from High Selenium Broccoli Protects Rats from Colon Cancer," The Journal of Nutrition, Vol. 130, No. 9, 2000, pp. 2384-2389.

[76] A. Bibak, S. Sturup, L. Knudsen and V. Gundersen, "Concentration of 63 Elements in Cabbage and Sprouts in Denmark," Communications in Soil Science and Plant Analysis, Vol. 30, No. 17-18, 1999, pp. 2409-2418. doi:10.1080/00103629909370382

[77] K. H. Miean and S. Mohamed, "Flavonoid (Myricetin, Quercetin, Kaempferol, Luteolinand Apigenin) Content of Edible Tropical Plants," Journal of Agriculture and Food Chemistry, Vol. 49, No. 6, 2001, pp. 106-112. doi:10.1021/jf000892m

[78] M. G. Hertog, P. C. Hollman and M. B. Katan, "Content of Potentially Anticarcinogenic Flavonoids of 28 Vegetables and Fruits Commonly Consumed in the Netherlands," Journal of Agriculture and Food Chemistry, Vol. 40 , No. 12 , 1992, pp. 2379-2383. doi:10.1021/jf00024a011

[79] J. K. Nielson, C. E. Olsen and M. K. Petersen, "Acylated Flavonol Glycosides from Cabbage Leaves," Phytochemistry, Vol. 34, No. 2, 1993, pp. 539-544. doi:10.1016/0031-9422(93)80042-Q

[80] R. Kubec, M. Svobodovaand and J. Velisek, "Distribution of $S$-Alk(en)ylcysteine Sulfoxides in Some Allium Species. Identification of a New Flavour Precursor: $S$-Ethylcysteine Sulfoxide (ethiin)," Journal of Agriculture and Food Chemistry, Vol. 48, No. 2, 2000, pp. 428-433. doi:10.1021/jf990938f

[81] R. Kubec, M. Svobodova and J. Velisek, "Gas-Chromatographic Determination of S-Alk(eny)lylcysteine Sulfoxide," Journal of Chromatography, Vol. 862, 1999, pp. 85-94. doi:10.1016/S0021-9673(99)00902-4

[82] K. Herrmann, "Flavonols and Flavones in Food Plants: A Review," International Journal of Food Science and Technology, Vol. 11, No. 5, 1976, pp. 433-448. doi:10.1111/j.1365-2621.1976.tb00743.x

[83] A. Bilyk and G. M. Sapers, "Distribution of Quercetin and Kaemperol in Lettuce, Kale, Chive, Garlic Chive Leek, Horseradish, Red Radish and Red Cabbage Tissue," Journal of Agriculture and Food Chemistry, Vol. 33, 
1985, pp. 226-228. doi:10.1021/jf00062a017

[84] C. Ip and D. J. Lisk, "Enrichment of Selenium in Allium Vegetables for Cancer Prevention," Carcinogenesis, Vol. 15, No. 9, 1994, pp. 1881-1885.

doi:10.1093/carcin/15.9.1881

[85] K. El-Bayoumy, "The Role of Selenium in Cancer Prevention," In: V. T. DeVita, S. Hellman and S. A. Rosenberg, Eds., Cancer Principles and Practices of Oncology, Philadelphia, 1991, pp. 1-15.

[86] H. Wang, A. Kruszewki and D. L. Brautigan, "Cellular Chromium Activation of Insulin Receptor Kinase," Biochemistry, Vol. 44, No. 22, 2005, pp. 8167-8175. doi:10.1021/bi0473152

[87] T. Ritsema and S. Smeekens, "Fructans: Beneficial for Plants and Humans," Current Opinion in Plant Biology, Vol. 6, No. 3, 2003, pp. 223-230. doi:10.1016/S1369-5266(03)00034-7

[88] H. P. Kruse, B. Kleessen and M. Blaut, "Effects of Inulin on Faecal Bifidobacteria in Human Subjects," The British Journal of Nutrition, Vol. 82, No. 5, 1999, pp. 375-382.

[89] S. Kilian, S. Kritzinger, C. Rycroft, G. R. Gibson and J. Du Preez, "The Effects of the Novel Bifidogenic Trisacharide, Neokestose, on the Human Colonic Microbiota," World Journal of Microbiology \& Biotechnology, Vol. 18, No. 7, 2002, pp. 637-644. doi:10.1023/A:1016808015630

[90] K. E. Scholz-Ahrens, G. Schaafsma, E. G. H. M. Van Den Heuvel and J. Schrezenmeir, "Effects of Prebiotics on Mineral Metabolism," The American Journal of Clinical Nutrition, Vol. 73, No. 2, 2001, pp. 459-464.

[91] K. G. Jackson, G. R. Taylor, A. M. Clohessy and C. M. Willieams, "The Effect of the Daily Intake of Inulin on Fasting Lipid, Insulin and Glucose Concentrations in Middle-Aged Men and Women," The British Journal of Nutrition, Vol. 82, No. 1, 1999, pp. 23-30.

[92] K. Srinivasan, "Plant Foods in the Management of Diabetes Mellitus: Spices as Beneficial Antidiabetic Food Adjuncts," Internaional Journal of Food Science Nutrition, Vol. 56, No. 6, 2005, pp. 399-414. doi:10.1080/09637480500512872

[93] K. K. Sharma, R. K. Gupta, S. C. Gupta and K. C. Samuel, "Antithyperglycemic Effect of Onion: Effect on Fasting Blood Sugar and Induced Hyperglycemic in Man," Indian Journal of Medical Research, Vol. 65, No. 3, 1977, pp. 422-429.

[94] A. Tjokroprawiro, B. S. Pikir, A. A. Budhiarta, S. H. Pranawa, M. Deonosepoetro, F. X. Budhianto, J. A. Wibowo, S. J. Tanuwidjaja and M. Pangemanan, "Metabolic Effects of Onion and Green Beans on Diabetic Patients," The Tohoku Journal of Experimental Medicine, Vol. 141, 1983, pp. 671-676. doi:10.1620/tjem.141.Suppl_671

[95] E. Dorant, P. A. Van Den Brandt, R. A. Goldbohm and F. Sturnmans, "Comsumption of Onions and a Reduced Risk of Stomach Carcinoma," Gastroenterology, Vol. 110, No. 1, 1996, pp. 12-20. doi:10.1053/gast.1996.v110.pm8536847

[96] W. C. You, J. Y. Li, L. Zhang, M. L. Jin, Y. S. Chang, J. L. Ma and K. F. Pan, "Etiology and Prevention of Gastric Cancer: A Population Study in High Risk Area of China,"
Chinese Journal of Digestive Diseases, Vol. 6, No. 4, 2005, pp. 149-154.

doi:10.1111/j.1443-9573.2005.00222.x

[97] C. Galeone, C. Pelucchi, F. Levi, E. Negri, S. Franceschi, R. Talamini, A. Giacosa and C. La Vecchia, "Onion and Garlic Use and Human Cancer," The American Journal of Clinical Nutrition, Vol. 84, No. 5, 2006, pp. 1027-1032. doi:10.1002/ijc. 21336

[98] J. Y. Kim and O. Kwon, "Garlic Intake and Cancer Risk: An Analysis Using the Food and Drug Administration's Evidence-Based Review System for the Scientific Evaluation of Health Claims," The American Journal of Clinical Nutrition, Vol. 89, No. 1, 2009, pp. 257-264. doi:10.3945/ajen.2008.26142

[99] S. Salem, M. Salahi, M. Mohseni, H. Ahmadi, A. Mehrsai, Y. Jahani and G. Pourmand, "Major Dietary Factors and Prostate Cancer Risk: A Prospective Multicenter CaseControl Study," Nutrition and Cancer, Vol. 63, No. 1, 2011, pp. 21-27.

[100] W. C. You, L. Zhang, M. H. Gail, J. L. Ma, Y. S. Chang, W. J. Blot, J. Y. Li, C. L. Zhao, W. D. Liu, H. Q. Li, Y. R. Hu, J. C. Bravo, P. Correa, G. W. Xu and J. F. Fraumeni Jr., "Helicobacter Pylori Infection, Garlic Intake and Precancerous Lesions in a Chinese Population at Low Risk of Gastric Cancer," Internaional Journal of Epidemiology, Vol. 27, No. 6, 1998, pp. 941-944.

doi:10.1093/ije/27.6.941

[101] T. Takezaki, C. M. Gao, J. H. Ding, T. K. Liu, M. S. Li and K. Tajima, "Comparative Study of Lifestyles of Residents in High and Low Risk Areas for Gastric Cancer in Jiangsu Province, China with Special Reference to Allium Vegetables," Journal of Epidemiology, Vol. 9, No. 5, 1999, pp. 297-305. doi:10.2188/jea.9.297

[102] C. M. Gao, T. Takezaki, J. H. Ding, M. S. Li and K. Tajima, "Protective Effect of Allium Vegetables Against both Esophageal and Stomach Cancer: A Simultaneous Casereferent Study of a High-Epidemic Area in Jiangsu Province, China," Japanese Journal of Cancer Research, Vol. 90, No. 6, 1999, pp. 614-621. doi:10.1111/j.1349-7006.1999.tb00791.x

[103] E. Dorant, P. A. van den Brandt, R. A. Goldbohm and F. Sturmans, "Consumption of Onions and a Reduced Risk of Stomach Carcinoma," Gastroenterology, Vol. 110, No. 1, 1996, pp. 12-20. doi:10.1053/gast.1996.v110.pm8536847

[104] C. Pelucchi, C. Bosetti, M. Rossi, E. Negri and C. La Vecchia, "Selected Aspects of Mediterranean Diet and Cancer Risk," Nutrition and Cancer, Vol. 61, No. 6, 2009, pp. 756-766. doi:10.1080/01635580903285007

[105] T. Hirohata and S. Kono, "Diet/Nutrition and Stomach Cancer in Japan," International Journal of Cancer, Vol. 10, 1997, pp. 34-36. doi:10.1002/(SICI)1097-0215(1997)10+<34::AID-IJC9> 3.0.CO;2-A

[106] N. Munoz, M. Plummer, J. Vivas, V. Moreno, S. De Sanjose, G. Lopez and W. Oliver, "A Case-Control Study of Gastric Cancer in Venezuela," International Journal of Cancer, Vol. 93, No. 3, 2001, pp. 417-423. doi:10.1002/ijc. 1333 
[107] E. De Stefani, P. Correa, P. Boffetta, A. Ronco, P. Brennan, H. Deneo-Pellegrini and M. Mendilaharsu, "Plant Foods and Risk of Gastric Cancer: A Case-Control Study in Uruguay," European Journal of Cancer Prevention, Vol. 10, No. 4, 2001, pp. 357-364. doi:10.1097/00008469-200108000-00009

[108] A. T. Fleischauer, C. Poole and L. Arab, "Garlic Consumption and Cancer Prevention: Meta-Analyses of Colorectal and Stomach Cancers," The American Journal of Clinical Nutrition, Vol. 72, No. 4, 2000, pp. 1047-1052.

[109] A. W. Hsing, A. P. Chokkalingam, Y. T. Gao, M. P. Madigan, J. Deng, G. Gridley and J. F. Fraumeni Jr., "Allium Vegetables and Risk of Prostate Cancer: A Population-Based Study," Journal of the National Cancer Institute, Vol. 94, No. 21, 2002, pp. 1648-1651. doi:10.1093/jnci/94.21.1648

[110] S. Tanaka, K. Haruma, M. Kunihiro, S. Nagata, Y. Kitadai, N. Manabe, M. Sumii, M. Yoshihara, G. Kajiyama and K. Chayama, "Effects of Aged Garlic Extract (AGE) on Colorectal Adenomas: A Double-Blinded Study," $\mathrm{Hi}$ roshima Journal of Medical Sciences, Vol. 53, No. 3-4, 2004, pp. 39-45.

[111] S. Tanaka, K. Haruma, M. Yoshihara, G. Kajiyama, K. Kira, H. Amagase and K. Chayama, "Aged Garlic Extract Has Potential Suppressive Effect on Colorectal Adenomas in Humans," The Journal of Nutrition, Vol. 136, No. 3, 2006, pp. 821S-826S.

[112] W. B. Grant, "A Multicountry Ecologic Study of Risk and Risk Reduction Factors for Prostate Cancer Mortality," European Urology, Vol. 45, No. 3, 2004, pp. 271279. doi:10.1016/j.eururo.2003.08.018

[113] B. Challier, J. M. Perarnau and J. F. Viel, "Garlic, Onion and Cereal Fibre as Protective Factors for Breast Cancer: A French Case-Control Study," European Journal of Epidemiology, Vol. 14, No. 8, 1998, pp. 737-747. doi:10.1023/A:1007512825851

[114] C. Galeone, C. Pelucchi, L. Dal Maso, E. Negri, M. Montella, A. Zucchetto, R. Talamini and C. La Vecchia, "Allium Vegetables Intake and Endometrial Cancer Risk," Public Health Nutrition, Vol. 12, 2009, pp. 15761579. doi:10.1017/S1368980008003820

[115] J. A. Satia, A. Littman, C. G. Slatore, J. A. Galanko and E. White, "Associations of Herbal and Specialty Supplements with Lung and Colorectal Cancer Risk in the VITamins and Lifestyle Study," Cancer Epidemiology Biomarkers \& Prevention, Vol. 18, No. 5, 2009, pp. 14191428. doi:10.1158/1055-9965.EPI-09-0038

[116] A. Herman-Antosiewicz, A. A. Powolny and S. V. Singh, "Molecular Targets of Cancer Chemoprevention by Garlic-Derived Organosulfides," Acta Pharmacological Sinica, Vol. 28, No. 9, 2007, pp. 1355-1364. doi:10.1111/j.1745-7254.2007.00682.x

[117] M. Iciek, I. Kwiecien and L. Wlodek, "Biological Properties of Garlic and Garlic-Derived Organosulfur Compounds," Environmental and Molecular Mutagenesis, Vol. 50, No. 3, 2009, pp. 247-265. doi:10.1002/em.20474

[118] S. Melino, R. Sabelli and M. Paci, "Allyl Sulfur Compounds and Cellular Detoxification System: Effects and Perspectives in Cancer Therapy," Amino Acids, Vol. 41,
No. 1, 2011, pp. 103-112. doi:10.1007/s00726-010-0522-6

[119] M. Y. Shon, S. D. Choi, G. G. Kahng, S. H. Nam and N. J. Sung, "Antimutagenic, Antioxidant and Free Radical Scavenging Activity of Ethyl Acetate Extracts from White, Yellow and Red Onions," Food Chemical Toxicology, Vol. 42, No. 4, 2004, pp. 659-666. doi:10.1016/j.fct.2003.12.002

[120] J. Yang, K. J. Meyers, J. Van der Heide and R. H. Liu, "Varietal Differences in Phenolic Content and Antioxidant and Antiproliferative Activities of Onions," Journal of Agriculture and Food Chemistry, Vol. 52, No. 22, 2004, pp. 6787-6793. doi:10.1021/jf0307144

[121] K. S. Osmont, C. R. Arnt and I. L. Goldman, "Temporal Aspects of Onion-Induced Antiplatelet Activity," Plant Foods for Human Nutrition, Vol. 58, No. 1, 2003, pp. 27-40. doi:10.1023/A:1024062330700

[122] G. P. Hubbard, S. Wolffram, J. A. Lovegrove and J. M. Gibbins, "Ingestion of Quercetin Inhibits Platelet Aggregation and Essential Components of the Collagen-Stimulated Platelet Activation Pathway in Man: A Pilot Study," The British Journal of Nutrition, Vol. 96, No. 3, 2006, pp. 2138-2145.

[123] S. Clinton, "Lycopene: Chemistry, Biology and Implication for Human Health and Disease," Nutrition Reviews, Vol. 56, No. 2, 1998, pp. 35-51. doi:10.1111/j.1753-4887.1998.tb01691.x

[124] K. J. Scott and D. J. Hart, "Development and Evolution of an HPLC Method for the Analysis of Carotenoids Food and the Measurement of the Carotenoid Content Vegetables and Fruits Commonly Consumed in the UK," Food Chemistry, Vol. 54, 1995, pp. 101-111. doi:10.1016/0308-8146(95)92669-B

[125] L. H. Tonucci, J. M. Holden, G. R. Beecher, F. Khachik, C. S. Davis and G. Mulokozi, "Carotenoid Content of Thermally Processed Tomato-Based Food Products," Journal of Agriculture and Food Chemistry, Vol. 43, No. 3, 1995, pp. 579-586. doi:10.1021/jf00051a005

[126] H. Gerster, "The Potential Role of Lycopene for Human Health," Journal of the American College of Nutrition, Vol. 16, No. 2, 1997, pp. 109-126.

[127] A. V. Rao, Z. Waseem and S. Agarwal, "Lycopene Contents of Tomatoes and Tomato Products and Their Contribution to Dietary Lycopene," Food Research International, Vol. 31, No. 10, 1998, pp. 737-741. doi:10.1016/S0963-9969(99)00053-8

[128] A. A. Albushita, H. G. Daood and P. A. Biacs, "Change in Carotenoids and Antioxidant Vitamins in Tomato as a Function of Varietal and Technological Factors," Journal of Agriculture and Food Chemistry, Vol. 48, No. 6, 2000, pp. 2075-2081. doi:10.1021/jf990715p

[129] C. Leonardi, P. Ambrosino, F. Esposito and V. Fogliano, "Antioxidant Activity and Caroteoid and Tomatine Contentes in Different Typologies of Fresh Consumption Tomatoes," Journal of Agriculture and Food Chemistry, Vol. 48, No. 10, 2000, pp. 4723-4727. doi:10.1021/jf000225t

[130] L. Arab and S. Steck, "Lycopene and Cardiovascular Disease," The American Journal of Clinical Nutrition, 
Vol. 71, No. 6, 2000, pp. 1691S-1695S.

[131] United States Department of Agriculture, "USDA National Nutrient Database for Standard Reference,” 2009. http://www.nal.usda.gov/fnic/foodcomp/Data/SR20/nutrli st/sr20w309.pdf

[132] Dietary Guidelines Advisory Committee, "Report of the Dietary Guidelines Advisory Committee," 2005. http://www.health.gov/dietaryguidelines/dga2005/report/ HTML/C_Methodology.htm

[133] Food and Nutrition Board, "Water and Electrolytes. Recommended Dietary Allowances," National Academies Press, Washington DC, 1989, pp. 247-261. doi:10.1021/jf000225t

[134] Food and Nutrition Board, "Panel on Dietary Intakes for Electrolytes and Water. Potassium. Dietary Reference Intakes for Water, Potassium, Sodium, Chloride, and Sulfate," National Academies Press, Washington DC, 2005.

[135] A. V. Rao and L. G. Rao, "Carotenoids and Human Health," Pharmacological Research, Vol. 55, No. 3, 2007, pp. 207-216. doi:10.1016/j.phrs.2007.01.012

[136] A. A. Albushita, E. A. Hebshi, H. G. Daood and P. A. Biacs, "Determination of Antioxidant Vitamins in Tomato," Food Chemistry, Vol. 60, No. 2, 1997, pp. 207212. doi:10.1016/S0308-8146(96)00321-4

[137] A. J. Stewart, S. Bozonnet, W. Mullen, G. I. Jenkins, M. E. Lean and A. Crozier, "Occurrence of Flavonols in Tomatoes and Tomato-Based Products," Journal of Agriculture and Food Chemistry, Vol. 48, No. 7, 2000, pp. 2663-2669. doi:10.1021/jf000070p

[138] A. Crozier, M. E. Lean, M. S. McDonaldand and C. Black, "Quantitative Analysis of the Flavonoid Content of Commercial Tomatoes, Onions, Lettuceand Celery," Journal of Agriculture and Food Chemistry, Vol. 45, No. 3, 1997, pp. 590-595. doi:10.1021/jf960339y

[139] C. M. Allen, S. J. Schwartz, N. E. Craft, E. L. Giovannucci, V. L. De Groff and S. K. Clinton, "Changes in Plasma and Oral Mucosal Lycopene Isomer Concentrations in Healthy Adults Consuming Standard Servings of Processed Tomato Products," Nutrition and Cancer, Vol. 47, No. 1, 2003, pp. 48-56. doi:10.1207/s15327914nc4701 6

[140] R. Re, G. D. Mishra, C. W. Thane and C. J. Bates, "Tomato Consumption and Plasma Lycopene Concentration in People Aged 65 and over in a British National Survey," European Journal of Clinical Nutrition, Vol. 57, No. 12, 2003, pp. 1545-1554. doi:10.1038/sj.ejen.1601723

[141] V. Ganji and M. R. Kafai, "Population Determinants of Serum Lycopene Concentrations in the United States: Data from the Third National Health and Nutrition Examination Survey, 1988-1994," The Journal of Nutrition, Vol. 135, No. 3, 2005, pp. 567-572.

[142] P. G. Burney, G. W. Comstock and J. S. Morris, "Serologic Precursors of Cancer: Serum Micronutrients and the Subsequent Risk of Pancreatic Cancer," The American Journal of Clinical Nutrition, Vol. 49, No. 5, 1989, pp. 895-900.

[143] J. Van Eenwyk, F. G. Davis and P. E. Bowen, "Dietary and Serum Carotenoids and Cervical Intraepithelial Neoplasia," International Journal of Cancer, Vol. 48, No. 1, 1991, pp. 34-38. doi:10.1002/ijc.2910480107

[144] S. Franceschi, E. Bidoli, C. La Vecchia, R. Talamini, B. D'Avanzo and E. Negri, "Tomatoes and Risk of Digestive-Tract Cancers," International Journal of Cancer, Vol. 59, No. 2, 1994, pp. 181-184. doi:10.1002/ijc. 2910590207

[145] K. J. Helzlsouer, G. W. Comstock and J. S. Morris, "Selenium, Lycopene, Alpha-Tocopherol, Beta-Carotene, Retinol and Subsequent Bladder Cancer," Cancer Research, Vol. 49, 1989, pp. 6144-6148.

[146] P. H. Gann, J. Ma and E. Giovannucci, "Lower Prostate Cancer Risk in Men with Elevated Plasma Lycopene Levels: Results of a Prospective Analysis," Cancer Research, Vol. 59, No. 6, 1999, pp. 1225-1230.

[147] J. M. Yuan, R. K. Ross, Y. T. Gao, Y. H. Qu, X. D. Chu and M. C. Yu, "Prediagnostic Levels of Serum Micronutrients in Relation to Risk of Gastric Cancer in Shanghai, China," Cancer Epidemiology Biomarkers \& Prevention, Vol. 13, No. 1, 2004, pp. 1772-1780.

[148] K. Wakai, M. Ando and K. Ozasa, "Updated Information on Risk Factors for Lung Cancer: Findings from the JACC Study," Journal of Epidemiology, Vol. 15, No. 2, 2005, pp. S134-S139. doi:10.2188/jea.15.S134

[149] C. J. Foy, A. P. Passmore, M. D. Vahidassr, I. S. Young and J. T. Lawson, "Plasma Chain-Breaking Antioxidants in Alzheimer's Disease, Vascular Dementia and Parkinson's Disease," QJM: An International Journal of Medicine, Vol. 92, No. 1, 1999, pp. 39-45.

doi:10.1093/qimed/92.1.39

[150] P. Mecocci, M. C. Polidori and A. Cherubini, "Lymphocyte Oxidative DNA Damage and Plasma Antioxidants in Alzheimer Disease," Archives of Neurology, Vol. 59, No. 5, 2002, pp. 794-798. doi:10.1001/archneur.59.5.794

[151] M. C. Polidori, P. Mattioli and S. Aldred, "Plasma antioxidant Status, Immunoglobulin G Oxidation and Lipid Peroxidation in Demented Patients: Relevance to Alzheimer Disease and Vascular Dementia," Dementia and Geriatric Cognitive Disorders, Vol. 18, No. 3-4, 2004, pp. 265-270. doi:10.1159/000080027

[152] H. D. Sesso, J. E. Buring, E. P. Norkus and J. M. Gaziano, "Plasma Lycopene, Other Carotenoids, and Retinol and the Risk of Cardiovascular Disease in Women," The American Journal of Clinical Nutrition, Vol. 79, No. 1, 2004, pp. 47-53.

[153] D. Maggio, M. C. Polidori and M. Barabani, "Low Levels of Carotenoids and Retinol in Involution Osteoporosis," Bone, Vol. 38, No. 2, 2006, pp. 244-248. doi:10.1016/j.bone.2005.08.003

[154] L. F. Anderson, D. R. Jacobs, M. D. Gross, P. A. Schreiner, D. O. Williams and D. H. Lee, "Longitudinal Associations between Body Mass Index and Serum Carotenoids: The CARDIA Study," British Journal of Nutrition, Vol. 95, No. 2, 2006, pp. 358-365. doi:10.1079/BJN20051638

[155] L. G. Rao, E. S. Mackinnon, R. G. Josse, T. M. Murray, A. Strauss and A. V. Rao, "Lycopene Consumption De- 
creases Oxidative Stress and Bone Resorption Markers in Postmenopausal Women," Osteoporosis International, Vol. 18, No. 1, 2007, pp. 109-115. doi:10.1007/s00198-006-0205-Z

[156] Z. Yang, Z. Zhang, K. L. Penniston, N. Binkley and S. A. Tanumihardjo, "Serum Carotenoid Concentrations in Postmenopausal Women from the United States with and without Osteoporosis," Internatonal Journal for Vitamin and Nutrition Research, Vol. 78, No. 3, 2008, pp. 105111. doi:10.1024/0300-9831.78.3.105

[157] L. L. Marchand, C. N. Yoshizawa, L. N. Kolonel, J. H. Hankin and M. T. Goodman, "Vegetable Consumption and Lung Cancer Risk: A Population-Based Case-Control Study in Hawaii," Journal of the National Cancer Institute, Vol. 81, No. 15, 1989, pp. 1158-1164. doi:10.1093/jnci/81.15.1158

[158] E. De Stefani, F. Oreggia, P. Boffetta, H. Deneo-Pellegrini, A. Ronco and M. Mendilaharsu, "Tomatoes, Tomato-Rich Foods, Lycopene and Cancer of the Upper Aerodigestive Tract: A Case-Control in Uruguay," Oral Oncology, Vol. 36, No. 1, 2000, pp. 47-53. doi:10.1016/S1368-8375(99)00050-0

[159] J. E. Upritchard, W. H. Sutherland and J. I. Mann, "Effect of Supplementation with Tomato Juice, Vitamin E and Vitamin C on LDL Oxidation and Products of Inflammatory Activity in Type 2 Diabetes," Diabetes Care, Vol. 23, 2000, pp. 733-738. doi:10.2337/diacare.23.6.733

[160] L. A. Mucci, R. Tamimi and P. Lagiou, "Are Dietary Influences on the Risk of Prostate Cancer Mediated through the Insulin-Like Growth Factor System," BJU International, Vol. 87, No. 9, 2001, pp. 814-820. doi:10.1046/j.1464-410x.2001.02191.x

[161] L. Chen, M. Stacewicz-Sapuntzakis and C. Duncan, "Oxidative DNA Damage in Prostate Cancer Patients Consuming Tomato Sauce-Based Entrees as a Whole-Food Intervention," Journal of the National Cancer Institute, Vol. 93, 2001, pp. 1872-1879. doi:10.1093/jnci/93.24.1872

[162] E. Giovannucci, E. B. Rimm, Y. Liu, M. J. Stampfer and W. C. Willett, "A Prospective Study of Tomato Products, Lycopene, and Prostate Cancer Risk," Journal of the National Cancer Institute, Vol. 94, No. 5, 2002, pp. 391-398. doi:10.1093/jnci/94.5.391

[163] P. Bowen, L. Chen and M. Stacewicz-Sapuntzakis, "Tomato Sauce Supplementation and Prostate Cancer: Lycopene Accumulation and Modulation of Biomarkers of Carcinogenesis," Experimental Biology and Medicine, Vol. 227, No. 10, 2002, pp. 886-893.

[164] C. W. Hadley, S. K. Clinton and S. J. Schwartz, "The Consumption of Processed Tomato Products Enhances Plasma Lycopene Concentrations in Association with a Reduced Lipoprotein Sensitivity to Oxidative Damage," The Journal of Nutrition, Vol. 133, No. 3, 2003, pp. 727-732.

[165] H. S. Kim, P. Bowen and L. Chen, "Effects of Tomato Sauce Consumption on Apoptotic Cell Death in Prostate Benign Hyperplasia and Carcinoma," Nutrition and Cancer, Vol. 47, No. 1, 2003, pp. 40-47. doi:10.1207/s15327914nc4701 5

[166] A. Bub, S. W. Barth, B. Watzl, K. Briviba and G. Rechkemmer, "Paraoxonase 1 Q192R (PON1-192) Polymorphism Is Associated with Reduced Lipid Peroxidation in Healthy Young Men on a Low-Carotenoid Diet Supplemented with Tomato Juice," The British Journal of Nutrition, Vol. 93, No. 3, 2005, pp. 291-297. doi:10.1079/BJN20041309

[167] L. Jian, C. J. Du, A. H. Lee and C. W. Binns, "Do Dietary Lycopene and Other Carotenoids Protect against Prostate Cancer," International Journal of Cancer, Vol. 113, No. 6, 2005, pp. 1010-1014. doi:10.1002/ijc.20667

[168] W. Stahl, U. Heinrich, S. Wiseman, O. Eichler, H. Sies and H. Tronnier, "Dietary Tomato Paste Protects against Ultraviolet Light-Induced Erythema in Humans," The Journal of Nutrition, Vol. 131, No. 5, 2001, pp. 1449-1451.

[169] W. Stahl, U. Heinrich, O. Aust, H. Tronnier and H. Sies, "Lycopene-Rich Products and Dietary Photoprotection," Photochemical Photobiology Science, Vol. 5, No. 2, 2006, pp. 238-242. doi:10.1039/b505312a

[170] S. Walfisch, Y. Walfisch and E. Kirilov, "Tomato Lycopene Extract Supplementation Decreases Insulin-Like Growth Factor-I Levels in Colon Cancer Patients," European Journal of Cancer Prevention, Vol. 16, No. 4, 2007, pp. 298-303. doi:10.1097/01.cej.0000236251.09232.7b

[171] K. Jacob, M. J. Periago, V. Bohm and G. R. Berruezo, "Influence of Lycopene and Vitamin C from Tomato Juice on Biomarkers of Oxidative Stress and Inflammation," British Journal of Nutrition, Vol. 99, No. 1, 2008, pp. 137-146. doi:10.1017/S0007114507791894

[172] E. Paran, V. Novack, Y. N. Engelhard and I. Hazan-Halevy, "The Effects of Natural Antioxidants from Tomato Extract in Treated but Uncontrolled Hypertensive Patients," Cardiovascular Drugs and Therapy, Vol. 23, No. 2, 2009, pp. 145-151. doi:10.1007/s10557-008-6155-2

[173] B. Burton-Freeman and K. Reimers, "Tomato Consumption and Health: Emerging Benefits," American Journal of Lifestyle Medicine, Vol. 5, No. 2, 2011, pp. 182-191. doi:10.1177/1559827610387488

[174] M. S. Edinger and W. J. Koff, "Effect of the Consumption of Tomato Paste on Plasma Prostate-Specific Antigen Levels in Patients with Benign Prostate Hyperplasia," Brazilian Journal of Medical and Biological Research, Vol. 39, No. 8, 2006, pp. 1115-1119. doi:10.1590/S0100-879X2006000800014

[175] E. M. Grainger, S. J. Schwartz and S. Wang, “A Combination of Tomato and Soy Products for Men with Recurring Prostate Cancer and Rising Prostate Specific Antigen," Nutrition and Cancer, Vol. 60, No. 2, 2008, pp. 145-154. doi:10.1080/01635580701621338

[176] S. Schwarz, U. C. Obermuller-Jevic, E. Hellmis, W. Koch, G. Jacobi and H. K. Biesalski, "Lycopene Inhibits Disease Progression in Patients with Benign Prostate Hyperplasia," The Journal of Nutrition, Vol. 138, No. 1, 2008, pp. 49-53.

[177] E. Giovannucci, A. Ashcerio and E. B. Rimm, "Intake of Carotenoids and Retinol in Relation to Risk of Prostate Cancer," Journal of the National Cancer Institute, Vol. 
87, No. 23, 1995, pp. 1767-1776. doi:10.1093/jnci/87.23.1767

[178] E. Giovannucci, "Tomatoes, Tomato-Based Products, Lycopene, and Cancer: Review of the Epidemiological Literature," Journal of the National Cancer Institute, Vol. 91, No. 4, 1999, pp. 317-331. doi:10.1093/jnci/91.4.317

[179] K. Briviba, K. Schnabele, G. Rechkemmer and A. Bub, "Supplementation of a Diet Low in Carotenoids with Tomato or Carrot Juice Does Not Affect Lipid Peroxidation in Plasma and Feces of Healthy Men," The Journal of Nutrition, Vol. 134, No. 5, 2004, pp. 1081-1083.

[180] D. Steinberg, "Low Density Lipoprotein Oxidation and Its Pathobiological Significance," The Journal of Biological Chemistry, Vol. 272, 1997, pp. 20963-20966. doi:10.1074/jbc.272.34.20963

[181] K. S. Bose and B. K. Agrawal, "Effect of Long Term Supplementation of Tomatoes (Cooked) on Levels of Antioxidant Enzymes, Lipid Peroxidation Rate, Lipid Profile and Glycated Haemoglobin in Type 2 Diabetes Mellitus," West Indian Medical Journal, Vol. 55, No. 4, 2006, pp. 274-278.doi:10.1590/S0043-31442006000400010

[182] M. Porrini and P. Riso, "Lymphocyte Lycopene Concentration and DNA Protection from Oxidative Damage Is Increased in Women after a Short Period of Tomato Consumption," The Journal of Nutrition, Vol. 130, No. 2, 2000, pp. 189-192.

[183] M. Porrini, P. Riso and G. Oriani, "Spinach and Tomato Consumption Increases Lymphocyte DNA Resistance to Oxidative Stress but This Is Not Related to Cell Carotenoid Concentrations," European Journal of Nutrition, Vol. 41, No. 3, 2002, pp. 95-100. doi:10.1007/s003940200014

[184] A. Visioli, P. Riso, S. Grande, C. Galli and M. Porrini, "Protective Activity of Tomato Products on in Vivo Markers of Lipid Oxidation," European Journal of Nutrition, Vol. 42, No. 4, 2003, pp. 201-206. doi:10.1007/s00394-003-0415-5

[185] N. O'Kennedy, L. Crosbie and S. Whelan, "Effects of Tomato Extract on Platelet Function: A Double-Blinded Crossover Study in Healthy Humans," The American Journal of Clinical Nutrition, Vol. 84, No. 3, 2006, pp. 561-569.

[186] W. Stahl and H. Sies, "Carotenoids and Protection against Solar UV Radiation," Skin Pharmacology and Applied Skin Physiology, Vol. 15, No. 5, 2002, pp. 291-296. doi:10.1159/000064532

[187] N. Wattanapenpaiboon, W. Lukito, M. L. Wahlqvist and B. J. Strauss, "Dietary Carotenoid Intake as a Predictor of Bone Mineral Density," Asia Pacific Journal of Clinical Nutrition, Vol. 12, No. 4, 2003, pp. 467-473.

[188] S. Sahni, M. T. Hannan, J. Blumberg, L. A. Cupples, D. P. Kiel and K. L. Tucker, "Protective Effect of Total Carotenoid and Lycopene Intake on the Risk of Hip Fracture: A 17-Year Follow-Up from the Framingham Osteoporosis Study," Journal of Bone and Mineral Research, Vol. 24, No. 6, 2009, pp. 1086-1094. doi:10.1359/jbmr.090102

[189] S. Sahni, M. T. Hannan, J. Blumberg, L. A. Cupples, D. P. Kiel and K. L. Tucker, "Inverse Association of Carotenoid Intakes with 4-y Change in Bone Mineral Density in
Elderly Men and Women: The Framingham Osteoporosis Study," The American Journal of Clinical Nutrition, Vol. 89, No. 1, 2009, pp. 416-424 doi:10.3945/ajen.2008.26388

[190] P. Rinaldi, M. C. Polidori and A. Metastasio, "Plasma Antioxidants Are Similarly Depleted in Mild Cognitive Impairment and in Alzheimer's Disease," Neurobiology of Aging, Vol. 24, No. 7, 2003, pp. 915-919. doi:10.1016/S0197-4580(03)00031-9

[191] M. C. Polidori and P. Mecocci, "Plasma Susceptibility to Free Radical-Induced Antioxidant Consumption and Lipid Peroxidation Is Increased in Very Old Subjects with Alzheimer Disease," Journal of Alzheimer's Disease, Vol. 4, No. 6, 2002, pp. 517-522.

[192] A. Raben, A. Tagliabue, N. J. Christensen, J. Madsen, J. J. Holst and A. Astrup, "Resistant Starch: The Effect on Postprandial Glycemia, Hormonal Response, and Satiety," The American Journal of Clinical Nutrition, Vol. 60, No. 4, 1994, pp. 544-551.

[193] J. H. Cummings, E. R. Beatty, S. M. Kingman, S. A. Bingham and H. N. Englyst, "Digestion and Physiological Properties of Resistant Starch in the Human Large Bowel," British Journal of Nutrition, Vol. 75, No. 5, 1996, pp. 733-747. doi:10.1079/BJN19960177

[194] S. Hylla, A. Gostner and G. Dusel, "Effects of Resistant Starch on the Colon in Healthy Volunteers: Possible Implications for Cancer Prevention," The American Journal of Clinical Nutrition, Vol. 67, No. 1, 1998, pp. 136142.

[195] H. N. Englyst, S. M. Kingman and J. H. Cummings, "Classification and Measurement of Nutritionally Important Starch Fractions," European Journal of Clinical Nutrition, Vol. 46, No. 2, 1992, pp. S33-S50.

[196] University of California and National Center for Food Safety and Technology, "Lose the Weight, NOT the Potatoes," 2010 .

http://www.healthypotato.com/MediaCenter/LosetheWeig htNOT thePotatoes.php

[197] G. Fernandes, A. Velangi and T. M. S. Wolever, "Glycemic Index of Potatoes Commonly Consumed in North America," Journal of the American Dietetic Association, Vol. 105, No. 4, 2005, pp. 557-562. doi:10.1016/i.jada.2005.01.003

[198] C. M. McCay, J. B. McCay and O. Smith, "Nutritive Value of Potato," In: W. F. Talburt and O. Smith, Eds., Potato Processing, Westport, 1987, pp. 287-331.

[199] J. Okeyo and M. Kushad, "Composition of Four Potato Cultivars in Relation to Cold Storage and Reconditioning," HortTechnology, Vol. 5, No. 3, 1995, pp. 250-253.

[200] M. Friedman, "Nutricional Value of Proteins from Different Food Sources: A Review," Journal of Agriculture and Food Chemistry, Vol. 44, No. 1, 1996, pp. 6-29. doi:10.1021/jf9400167

[201] M. Friedman, "Chemistry, Biochemistry and Dietary Role of Potato Polyphenols: A Review," Journal of Agriculture and Food Chemistry, Vol. 45, No. 5, 1997, pp. 15231540.doi:10.1021/jf960900s 
[202] C. S. Jung, H. M. Griffiths, D. M. De Jong, S. Cheng, M. Bodis and W. S. De Jong, "The Potato Plocus Codes for Flavonoid 3',5'-Hydroxylase," Tag Theoretical and Applied Genetics, Vol. 110, No. 2, 2005, pp. 269-275. doi:10.1007/s00122-004-1829-z

[203] R. M. Reeve, E. Hautala and M. L. Weaver, “Anatomy and Compositional Variation within Potatoes II. Phenolics, Enzymes and Other Minor Components," American Journal of Potato Research, Vol. 46, No. 10, 1969, pp. 374-386. doi:10.1007/BF02869558

[204] P. Thomas and M. R. Joshi, "Prevention of After-Cooking Darkening of Irradiated Potatoes," Potato Research, Vol. 20, No. 1, 1977, pp. 77-84. doi:10.1007/BF02362302

[205] M. S. Al-Saikhan, L. R. Howard and J. C. Miller, "Antioxidant Activity and Total Phenolics in Different Genotypes of Potato (Solanum tuberosum, L.)," Journal of Food Science, Vol. 60, No. 2, 1995, pp. 341-344. doi:10.1111/j.1365-2621.1995.tb05668.x

[206] D. Hasegawa, R. M. Johnson and W. A. Gould, "Changes during Storage, Effect of Cold Storage on Chlorogenic Acid Content of Potatoes," Journal of Agriculture and Food Chemistry, Vol. 14, No. 2, 1966, pp. 165-169. doi:10.1021/jf60144a020

[207] E. Cieslik, "The Effect of Naturally Occurring Vitamin C in Potato Tubers on the Levels of Nitrates and Nitriles," Food Chemistry, Vol. 49, No. 3, 1994, pp. 233-235. doi:10.1016/0308-8146(94)90165-1

[208] M. Hagg, R. Hakkinen, J. Kumpulainen, R. Ahvenainen and E. Hurme, "Effects of Preparation Procedures, Packaging and Storage on Nutrient Retention of Peeled Potatos," Journal of the Science of Food and Agriculture, Vol. 77, No. 4, 1998, pp. 519-526. doi:10.1002/(SICI)1097-0010(199808)77:4<519::AID-JS FA75>3.0.CO;2-C

[209] A. S. Ong and E. S. Tee, "Natural Sources of Carotenoids from Plants and Oils," Methods in Enzymology, Vol. 213, 1992, pp. 142-167. doi:10.1016/0076-6879(92)13118-H

[210] L. Packer, "Vitamin E Is Nature's Master Antioxidant," Science \& Medicine, Vol. 1, No. 1, 1994, pp. 54-63.

[211] J. Lachman, J. K. Hamouz, M. Orsak and V. Pivec, "Potato Tubers as a Significant Source of Antioxidants in Human Nutrition," Rostlinná Výroba, Vol. 46, No. 5, 2000, pp. 231-236.

[212] I. Djujic, B. Djujic and L. Trajkovic, "Dietary Intake of Selenium in Serbia: Results for 1991 Conference Selenium," Nauc. Skup. Srp. Akad. Nauk. Umet, Vol. 6, 1995, pp. 81-87.

[213] P. W. Bosland, "Capsicums: Innovative Uses of an Ancient Crop," In: J. Janick, Ed., Progress in New Crops, ASHS Press, Arlington, 1996, pp. 479-487.

[214] L. R. Howard, S. T. Talcott, C. H. Brenes and B. Villalon, "Changes in Phytochemical and Antioxidant Activity of Selected Pepper Cultivars (Capsicum species) as Influenced by Maturity," Journal of Agriculture and Food Chemistry, Vol. 48, No. 5, 2000, pp. 1713-1720. doi:10.1021/jf990916t

[215] L. R. Howard, R. T. Smith, A. B. Wagner, B. Villalon and E. E. Burns, "Provitamin A and Ascorbic Acid Con- tent of Fresh Pepper Cultivars (Capsicum annum) and Processed Jalapenos," Journal of Food Science, Vol. 59, No. 2, 1994, pp. 362-365. doi:10.1111/j.1365-2621.1994.tb06967.x

[216] Y. Lee, R. Howard and B. Villalon, "Flavonoids and Antioxidant Activity of Fresh Pepper (Capsicum annum) Cultivars," Journal of Food Science, Vol. 60, No. 3, 1995, pp. 473-476.doi:10.1111/j.1365-2621.1995.tb09806.x

[217] E. K. Nelson, "The Constitution of Capsaicin, the Pungent Principle of Capsicum," Journal of the American Chemical Society, Vol. 41, No. 7, 1919, pp. 1115-1117. doi:10.1021/ja02228a011

[218] T. Suzuki and K. Iwai, "Constituents of Red Pepper Species: Chemistry, Biochemistry, Pharmacology, and Food Science of the Pungent Principle of Capsicum Species," In: A. Brossi, Ed., The Alkaloids, Academic Press, San Diego, 1984, pp. 227-299.

[219] A. M. Krajewska and J. J. Powers, "Sensory Properties of Naturally Occurring Capsaicinoids," Journal of Food Science, Vol. 53, No. 3, 1988, pp. 902-905. doi:10.1111/j.1365-2621.1988.tb08981.x

[220] B. V. Thomas, A. A. Schreilber and C. P. Weisskopf, "Simple Method for Quantitation of Capsaicinoids in Pepper Using Capillary Gas Chromatography," Journal of Agriculture and Food Chemistry, Vol. 46, No. 7, 1998, pp. 2655-2663. doi:10.1021/jf970695w

[221] A. Szallasi and P. M. Blumberg, "Vanilloid (Capsaicin) Receptors and Mechanisms," Pharmacological Reviews, Vol. 51, No. 2, 1999, pp. 159-211.

[222] B. Frei and S. Lawson, "Vitamin C and Cancer Revisited," Proceedings of the National Academy of Sciences (USA), Vol. 105, No. 32, 2008, pp. 11037-11038. doi:10.1073/pnas.0806433105

[223] Y. Noda, T. Kaneyuki, K. Igarashi, A. Moriand and L. Pacer, "Antioxidant Activity of Nasunin, an Anthocyanin in Eggplant," Research Communications in Molecular Pathology and Pharmacology, Vol. 102, No. 2, 1998, pp. 175-187.

[224] F. Kayamori and K. Igarashi, "Effect of Dietary Nasunin on the Serum Cholesterol Level in Rats," Bioscience, Biotechnology, and Biochemistry, Vol. 58, 1994, pp. 570571.

[225] Y. Noda, T. Kneyuki and K. Igarashi, "Antioxidant Activity of Nasunin, an Anthocyanin in Eggplant Peels," Toxicology, Vol. 148, No. 2-3, 2000, pp. 119-123.

[226] N. Matsuzoe, M. Yamaguchi, S. Kawanobu, Y. Watanabe, H. Higashi and Y. Sakata, "Effect of Dark Treatment of the Eggplant on Fruit Skin Color and Its Anthocyanin Components," Journal of the Japanese Society for Horticultural Science, Vol. 68, No. 1, 1999, pp. 138-145. doi:10.2503/jjshs. 68.138

[227] A. Ben-Amos and R. Fishler, "Analysis of Carotenoids with Emphasis on 9-cis $\beta$-carotene in Vegetables and Fruits Commonly Consumed in Israel," Food Chemistry, Vol. 62, No. 4, 1998, pp. 515-520.

[228] A. H. Ensminger, M. E. Esminger, J. E. Kondale and J. R. K. Robson, "Food for Health: A Nutrition Encyclopedia," Pegus Press, Inc., California, 1986. 
[229] R. Wood, "The Whole Foods Encyclopedia," PrenticeHall Press, New York, 1988.

[230] P. A. Jorge, L. C. Neyra and R. M. Osaki, "Effect of Eggplant on Plasma Lipid Levels, lipidic Peroxidation and Reversion of Endothelial Dysfunction in Experimental Hypercholesterolemia," Arquivos. Brasileiros de Cardiologia, Vol. 70, No. 2, 1998, pp. 87-91.

[231] P. R. Guimarães, A. M. Galvão, C. M. Batista, G. S. Azevedo, R. D. Oliveira, R. Lamounier, N. Freire, A. Barros, E. Sakurai, J. Oliveira, E. Vieira and J. AlvarezLeite, "Eggplant (Solanum melongena) Infusion Has a Modest and Transitory Effect on Hypercholesterolemic Subjects," Brazilian Journal of Medical and Biological Research, Vol. 33, No. 9, 2000, pp. 1027-1036. doi:10.1590/S0100-879X2000000900006

[232] J. M. Praça, A. Thomaz and B. Caramelli, "Eggplant (Solanum melongena) Extract Does Not Alter Serum Lipid Levels," Arquivos. Brasileiros de Cardiologia, Vol. 82, No. 3, 2004, pp. 273-276.

[233] H. Nagase, K. Sasaki, H. Kito, A. Haga and T. Sato, "Inhibitory Effect of Delphinidin from Solanum melongena on Human Fibrosarcoma HT-1080 Invasiveness in Vitro," Planta Meidica., Vol. 64, No. 3, 1998, pp. 216-219. doi:10.1055/s-2006-957412

[234] Y. I. Kwon, E. Apostolidis and K. Shetty, "In Vitro Studies of Eggplant (Solanum melongena) Phenolics as Inhibitors of Key Enzymes Relevant for Type 2 Diabetes and Hypertension," Bioresource Technology, Vol. 99, No. 8, 2008, pp. 2981-2988.

[235] E. F. Domino, E. Hornbach and T. Demana, "The Nicotine Content of Common Vegetables," The New England Journal of Medicine, Vol. 329, No. 437, 1993. doi:10.1056/NEJM199308053290619

[236] F. Parivar, R. K. Low and M. L. Stoller, "The Influence of Diet on Urinary Stone Disease," The Journal of Urology, Vol. 155, No. 2, 1996, pp. 432-440. doi:10.1016/S0022-5347(01)66411-5

[237] D. G. Assimos and R. P. Holmes, "Role of Diet in the Therapy of Urolithiasis," Urologic Clinics of North America, Vol. 27, No. 2, 2000, pp. 255-268. doi:10.1016/S0094-0143(05)70255-X

[238] S. Kikunaga, M. Arimori and M. Takahashi, "The Bioavailability of Calcium in Spinach and Calcium-Oxalate to Calcium-Deficient Rats," Journal of Nutritional Science and Vitaminology, Vol. 34, No. 2, 1988, pp. 195-207. doi:10.3177/jnsv.34.195 